\title{
Synthesis of diphenylphosphoryl enamines, 2-pyridones and 2-pyrrolidones
}

\author{
Elvira Peláez Arango, María José Iglesias, Ramón Álvarez-Manzaneda, and \\ Fernando López Ortiz*
}

\author{
Área de Química Orgánica, Universidad de Almería, Carretera de Sacramento, 04120, \\ Almería, Spain \\ E-mail:flortiz@ual.es
}

\section{Dedicated to Prof. Joan Bosch on the occasion of his $60^{\text {th }}$ birthday}

\begin{abstract}
$\beta$-Enamine phosphine oxides were prepared by an one-pot process involving the sequential reaction of triphenylphosphine oxide with methyl lithium and then with alkyl and aryl nitriles. The enamines added regioselectively through the $\beta$-carbon to the carbon-carbon triple bond of the DMAD with a stereoselectivity which depended on the substituent of the enamine. Heating the phosphoryl enamines afforded phosphorus substituted, 2-pyridones and 2-pyrrolidones in good to excellent yields. The cyclocondensation could also be performed without isolation of the intermediate adducts. The effects of the solvent and substituents bonded to the enamine moiety on the cyclocondensation process is discussed. The use of bulky substituents promotes alternative pathways for the reaction. Thus, when the enamine containing a tert-butyl group is heated in refluxing toluene, the expected 2-pyridone was not formed but a new 5dihenylphosporyl-2-hydroxy-3-pyrrolidone was isolated instead.
\end{abstract}

Keywords: 4-Diphenylphosphoryl-2-pyrrolidones, 5-diphenylphosphoryl-2-pyridones, 5diphenylphosphoryl-3-pyrrolydones, diphenylphosphorylenamines, phosphine oxides, phosphoryl substituted heterocycles

\section{Introduction}

Nitrogen heterocycles containing phosphorus functional groups are compounds of interest in many areas of industrial chemistry such as the textile, the pharmaceutical, the agricultural field, etc. ${ }^{1}$ A useful strategy for the preparation of these type of compounds is based on the cyclization of functionalized enamines. ${ }^{2} \beta$-Functionalized enamines or the corresponding imine tautomers derived from phosphonium salts, ${ }^{3}$ phosphine oxides, ${ }^{4}$ phosphonates, ${ }^{4 b, 4 d, 4 f, 5}$ and phosphazenes ${ }^{6}$ 
have been applied to the synthesis of phosphorus substituted three-, five- and six-membered nitrogen heterocycles. The heterocyclic framework available through this methodology includes azirines, pyrazoles, pyrroles, 2-pyrrolones, dihydro- and tetrahydropyridines, 2-pyridones, quinolines and pyrimidin-2,4-diones. Furthermore, phosphorus functionalized enamines are also useful starting materials for the preparation of phosphorus-containing heterocycles. ${ }^{7}$

We have previously reported the synthesis of 4-( $N$-acyl)phosphazenyl-2-pyrrolidones 7 and 5-( $N$-acyl)phosphazenyl-2-pyridones 8 by the intramolecular condensation reaction of polyfunctionalized enamines $\mathbf{6}$ bearing a $\left(N\right.$-acyl)phosphazenyl group on the $\beta$-carbon. ${ }^{6}$ The preparation of the phosphorus-containing enamines $\mathbf{6}$ precursors of the heterocycles involved five steps (Scheme 1): (i) formation of methyldiphenyl( $N$-phenyl)phosphazene through the Staudinger reaction of phenylazide with methyldiphenylphosphine, (ii) metallation of the phosphazene with $n$-BuLi followed by addition of a nitrile to obtain $\beta-[(N-$ phenyl)phosphazenyl]enamines, (iii) reduction of the $\mathrm{P}=\mathrm{N}$ linkage of the $(N-$ phenyl)phosphazenylenamines with $\mathrm{LiAlH}_{4}$ to the corresponding $\mathrm{P}(\mathrm{III})$ diphenylphosphinyl derivative $4^{8}$ (iv) a second Staudinger reaction of the enaminophosphines 4 with ethoxycarbonyl- or benzoylazide, and (v) addition of dimethyl acetylenedicarboxylate (DMAD) to the $\beta$-[(N-acyl $)$ phosphazenyl $]$ enamines. The cyclization of the enamines thus obtained was achieved by refluxing in $\mathrm{CH}_{3} \mathrm{CN}$ or toluene. The intermediate P- $(N-$ phenyl)enaminophosphazenes $\mathbf{3}$ was mandatory because the direct synthesis of $\mathbf{5}$ through the analogous reaction of $P$ - $(N$-acyl)phosphazenes afforded quantitatively $P$ - $(N$-acyl $)(N-$ imino)phosphazenes due to $\mathrm{C} \rightarrow \mathrm{N}$ migration of the phosphazenyl group. ${ }^{9}$

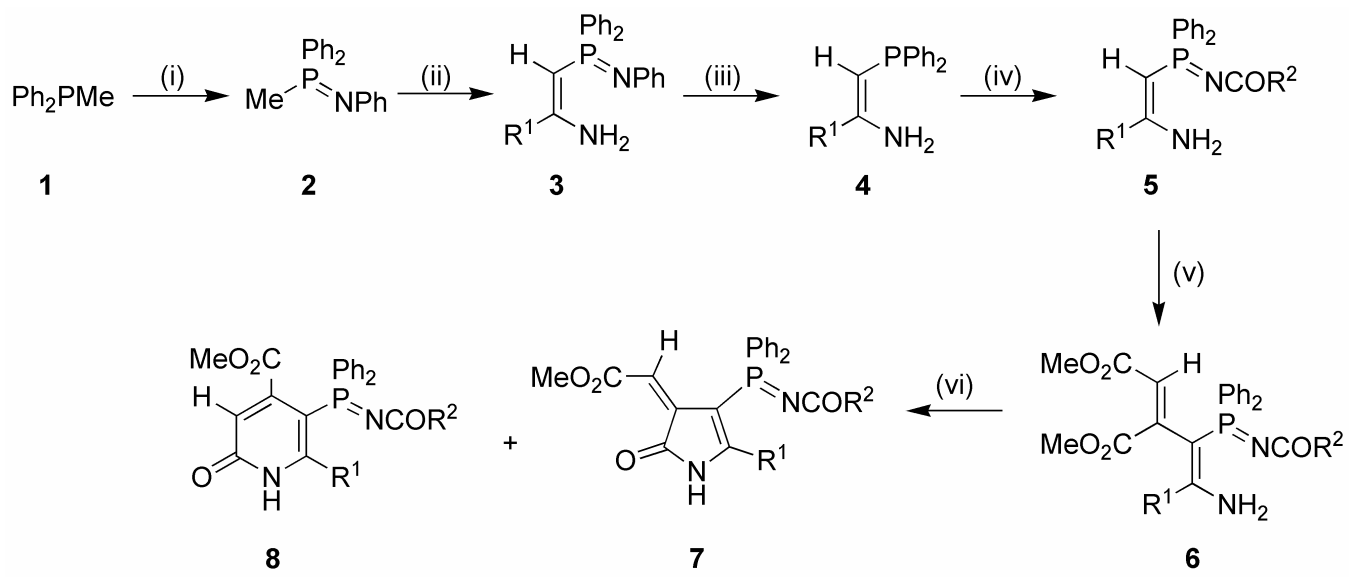

Scheme 1. (i) $\mathrm{PhN}_{3}, \mathrm{Et}_{2} \mathrm{O}, 25^{\circ} \mathrm{C}$. (ii) $n$-BuLi, THF, $-30{ }^{\circ} \mathrm{C}$ then $\mathrm{R}^{1} \mathrm{CN},-70{ }^{\circ} \mathrm{C}$. (iii) $\mathrm{LiAlH}_{4}$, THF. (iv) $\mathrm{N}_{3} \mathrm{COR}^{2}, \mathrm{Et}_{2} \mathrm{O}$. (v) DMAD, $\mathrm{CH}_{2} \mathrm{Cl}_{2}, 25^{\circ} \mathrm{C}$. (vi) $\mathrm{CH}_{2} \mathrm{Cl}_{2}$ or toluene, reflux.

Considering the importance of the phosphorus substituted heterocycles we decided to prepare derivatives of $\mathbf{7}$ and $\mathbf{8}$ having a $\mathrm{P}=\mathrm{O}$ group instead of the phosphazenyl moiety. This substituent is a useful surrogate of a carbonyl group in peptidomimetics, ${ }^{10}$ which might improve the molecular recognition ability of these compounds. Ogura et al. have recently shown that in 
the solid state the oxygen of phosphinoylated 2-pyridones is involved in the formation of chiral or achiral one dimensional structures through intermolecular hydrogen bonding with the hydrogen atom of the amide group. ${ }^{11}$ We report in this paper the synthesis of 4diphenylphosphoryl-2-pyrrolidones $\mathbf{1 1}$ and 5-diphenylphosphoryl-2-pyridones $\mathbf{1 2}$ in good to excellent yields in four steps starting from triphenylphosphine oxide. The use of the phosphine oxide functional group as the carrier of the phosphorus atom allowed a significant simplification of the synthetic procedure. Heating the adduct of phosphoryl enamines and DMAD in acetonitrile or toluene afforded the heterocycles 11 and 12. Steric effects slowed down the cyclocondensation reaction. The process could be accelerated by performing the transformation in boiling xylene. In the extreme case of a tert-butyl substituent the reaction proceeds through an alternative pathway leading to 5-diphenylphosphoryl-3-pyrrolidone 13.

\section{Results and Discussion}

\section{Synthesis of acyclic polyfunctionalized enamines}

Based on the synthesis of 2-pyrrolidones 7 and 2-pyridones 8 shown in Scheme 1 the preparation of the corresponding diphenylphosphoryl derivatives would require the use of $\beta$ diphenylphosphoryl enamines 9. These compounds have been previously obtained either by addition of nitriles to methyldiphenylphosphine oxide in the presence of a strong base (LDA or $n$-BuLi) or through the aza-Wittig reaction of phosphazenylenamines 3 with $\mathrm{CO}_{2}{ }^{12}$ A priori, the synthesis of enamines 9 could be carried out in a one-pot manner by taking into account that the intermediate lithiated phosphine oxide can be obtained almost quantitatively by displacement of a phenyl group of triphenylphoshine oxide with methyl lithium (Seyferth method). ${ }^{13}$ Indeed, this proved to be the case. The procedure consisted in the formation of lithium methylendiphenylphosphine oxide by treatment of triphenylphosphine oxide with methyl lithium in THF at $-30{ }^{\circ} \mathrm{C}$ during two hours, followed by the addition of the appropriated nitrile at $-70{ }^{\circ} \mathrm{C}$. The reaction was allowed to reach room temperature overnight and was then hydrolyzed with ice-water instead of using diluted hydrochloric acid $^{13 \mathrm{~b}}$ to avoid the transformation of the enamine moiety into the corresponding carbonyl compound (Scheme 2). The phosphoryl enamines 9 obtained, as well as their yields and ${ }^{31} \mathrm{P}$ chemical shifts are given in Table 1.

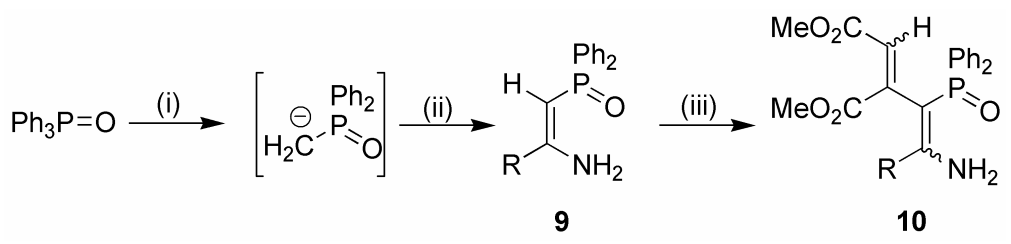

Scheme 2. (i) LiMe, THF, $-30^{\circ} \mathrm{C}, 2 \mathrm{~h}$. (ii) RCN, THF, $-70^{\circ}$ to $25^{\circ} \mathrm{C}, 8 \mathrm{~h}$. (iii) $\mathrm{DMAD}, \mathrm{CH}_{2} \mathrm{Cl}_{2}$, $25^{\circ} \mathrm{C}, 36 \mathrm{~h}$. 
Table 1. $\delta{ }^{31} \mathrm{P}(\mathrm{ppm})$ and yield (\%) for the $\beta$-phosphorylenamines 9

\begin{tabular}{cccc}
\hline Product & $\mathrm{R}$ & $\delta^{31} \mathrm{P}(\mathrm{ppm})$ & Yield (\%) \\
\hline \hline 9a & $p-\mathrm{CH}_{3}-\mathrm{C}_{6} \mathrm{H}_{4}$ & 30.1 & 85 \\
9b & $o-\mathrm{CH}_{3}-\mathrm{C}_{6} \mathrm{H}_{4}$ & 29.5 & 78 \\
9c & $\mathrm{C}_{6} \mathrm{H}_{11}$ & 30.4 & 89 \\
9d & ${ }^{t} \mathrm{Bu}$ & 30.6 & 89 \\
\hline
\end{tabular}

As expected, the reaction of DMAD with the phosphoryl enamines 9 in $\mathrm{CH}_{2} \mathrm{Cl}_{2}$ showed the same $C$-regioselectivity observed for the $\beta$-[(N-acyl $)$ phosphazenyl $]$ enamines derivatives ${ }^{6 a}$ yielding the aminodienic compounds $\mathbf{1 0}$ (Scheme 2, Table 2). The stereoselectivity of the process depended on the substituent $\mathrm{R}$ of the enamine. When $\mathrm{R}$ represented an aromatic ring, $\mathbf{1 0 a}-\mathbf{b}$, the reaction was stereospecific. The $Z$ geometry around the enamine moiety was retained and a cis-addition of the enamine $\mathrm{CH}$ bond to the triple bond in the DMAD took place, affording a conjugated dienic system with a $E, Z$ configuration exclusively. The structural assignment was based on the analysis of the vicinal phosphorus-carbon coupling constants and nuclear Overhauser enhancements (NOE) measured. A magnitude of ${ }^{3} J_{\mathrm{PC}} \approx 11 \mathrm{~Hz}$ for the ipso-carbon bonded to the enamine clearly established the anti arrangement of the two coupled nuclei around the double bond, which corresponded to a $Z$ configuration. ${ }^{14}$ This assignment is confirmed by the NOE detected between the methoxycarbonyl group bonded to the quaternary olefinic carbon and the aromatic protons of the $p$-tolyl substituent in $\mathbf{1 0 a}$, and the ortho methyl protons in $\mathbf{1 0 b}$. The $E$ configuration of the double bond conjugated with the enamine is deduced from NOE observed between the olefinic proton and the ortho protons of the aromatic rings bonded to the phosphorus. Interestingly, the saturation of these protons also produced a small NOE enhancement on protons corresponding to the substituent $\mathrm{R}$. These results are consistent with a non planar s-trans conformation of the dienic system, an arrangement already found in the analogous phosphazenyl enamines, Figure $1 .^{6 \mathrm{a}}$
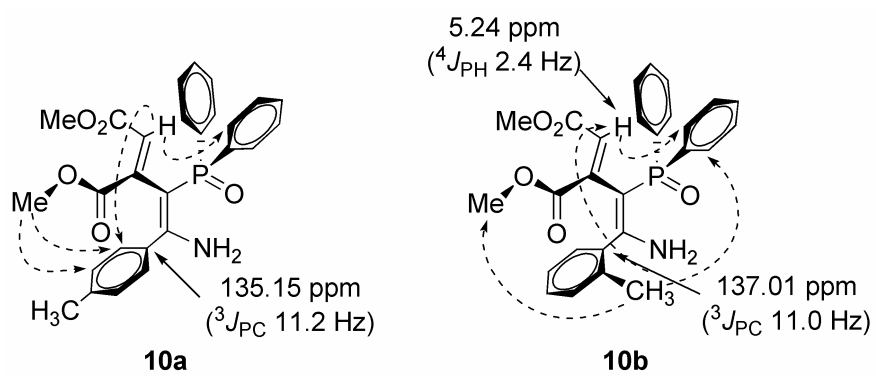

Figure 1. Selected NOE's for compounds $\mathbf{1 0 a}$ and $\mathbf{1 0 b}$ measured at $300.13 \mathrm{MHz}$ in $\mathrm{CDCl}_{3}$.

When $\mathrm{R}$ was aliphatic a mixture of stereoisomers was obtained. Thus, for $\mathrm{R}=\mathrm{C}_{6} \mathrm{H}_{11}$ the crude reaction mixture contained three aminodienes 10ca:10cb:10cc in a ratio 80:10:10 calculated from the integration of the ${ }^{31} \mathrm{P}$ NMR spectrum. All attempts to isolate these 
compounds failed and only mixtures of variable composition of the three compounds were obtained. The structural assignment could be carried out by analyzing again the magnitudes of ${ }^{3} J_{\mathrm{PC}}$ and the NOE data measured from the crude reaction mixture. On this basis, the three structures shown in Figure 2 were identified. Compounds 10ca and 10cc differed from each other in the configuration of the carbon-carbon double bond bearing the two methoxycarbonyl substituents. Both products retained the $Z$-configuration on the enamine moiety (configurational isomers $E, Z$ and $Z, Z$, respectively). Compound $\mathbf{1 0} \mathbf{c b}$ was assigned as the $Z, E$ isomer arising from the trans-addition of the enamine to the DMAD and inversion of the stereochemistry of the enamine linkage respect to the starting material. On standing in $\mathrm{CHCl}_{3}$ solution, compounds $10 \mathrm{ca}$ and $10 \mathrm{cb}$ isomerized to $10 \mathrm{cc}$, i.e. the product of kinetic control corresponds to the cisaddition of the enamine to the carbon-carbon triple bond of the DMAD, while the $Z, Z$ isomer is the product of thermodynamic control.
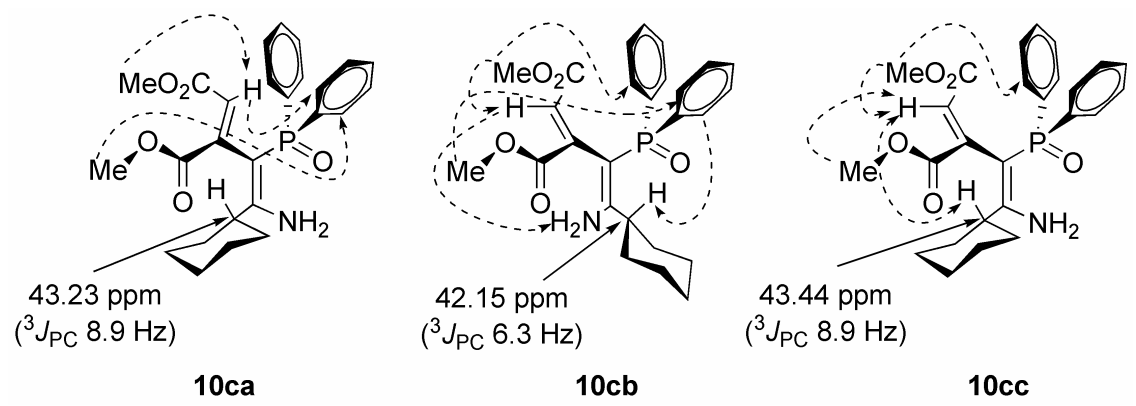

Figure 2. Selected NOEs for compounds $10 \mathrm{ca}, 10 \mathrm{cb}$ and $10 \mathrm{cc}$ measured at $300.13 \mathrm{MHz}$ in $\mathrm{CDCl}_{3}\left(10 \mathrm{cb}\right.$ and 10cc) and $\mathrm{C}_{6} \mathrm{D}_{6}(10 \mathrm{ca})$.

The reaction between the phosphoryl enamine $9 \mathrm{~d}, \mathrm{R}=t$-Bu, and DMAD also afforded a mixture of two compounds 10da:10db in a ratio 35:65, which could not be separated because all manipulations of the mixture promoted the cyclization of the components. The structural characterization was carried out from the crude reaction mixture through a combination of NMR experiments including NOE difference and 2D ${ }^{1} \mathrm{H},{ }^{13} \mathrm{C}$ HMQC and HMBC spectra. Compound 10da is the result of the stereospecific cis addition ${ }^{15}$ of enamine 9d to DMAD and the isomer $10 \mathrm{db}$ was identified as the imino tautomer of the enamine 10da. The correlations observed for the olefinic and methine protons in the HMBC spectrum established the connectivity of the carbon skeleton (Figure 3). The observation in solution of the imine tautomer of an enamine containing a $t$-butyl substituent is precedented in the literature. ${ }^{16}$ Moreover, 10db showed a significant broadening of some signals in the ${ }^{1} \mathrm{H}$ and ${ }^{13} \mathrm{C}$ NMR spectra. Variable temperature NMR measurements in different solvents $\left(\mathrm{CDCl}_{3}\right.$ and THF- $\left.d_{8}\right)$ combined with the analysis of the ROESY ${ }^{17}$ spectrum acquired at $-60{ }^{\circ} \mathrm{C}$ allowed to identify the existence of a cis-trans equilibrium of the imino moiety. ${ }^{18}$ Table 2 shows the polyfunctionalized phosphoryl enamines obtained in the reaction of 9 with DMAD. 

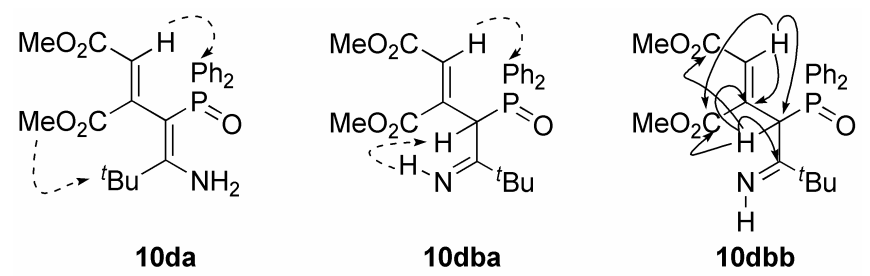

Figure 3. Structures of the compounds obtained in the reaction between the phosphoryl enamine 9d $\left(\mathrm{R}=t\right.$-Bu) and DMAD showing selected NOEs (dashed arrows) and ${ }^{1} \mathrm{H}{ }^{13} \mathrm{C}$ correlations (continuous arrows).

Table 2. $\delta{ }^{31} \mathrm{P}(\mathrm{ppm})$ and yield (\%) for compounds 10 obtained in the treatment of the phosphoryl enamines 9 with DMAD

\begin{tabular}{cccc}
\hline Product & $\mathrm{R}$ & $\delta^{31} \mathrm{P}(\mathrm{pppm})$ & Yield (\%) \\
\hline \hline 10a & $p-\mathrm{CH}_{3}-\mathrm{C}_{6} \mathrm{H}_{4}$ & 38.5 & $>97$ \\
$\mathbf{1 0 b}$ & $o-\mathrm{CH}_{3}-\mathrm{C}_{6} \mathrm{H}_{4}$ & 37.5 & $>97$ \\
$\mathbf{1 0 c a}$ & $\mathrm{C}_{6} \mathrm{H}_{11}$ & 36.4 & $80^{\mathrm{a}}$ \\
$\mathbf{1 0 c b}$ & $\mathrm{C}_{6} \mathrm{H}_{11}$ & 23.3 & $10^{\mathrm{a}}$ \\
$\mathbf{1 0 c c}$ & $\mathrm{C}_{6} \mathrm{H}_{11}$ & 31.4 & $10^{\mathrm{a}}$ \\
$\mathbf{1 0 d a}$ & ${ }^{t} \mathrm{Bu}$ & 37.2 & $35^{\mathrm{b}}$ \\
$\mathbf{1 0 d b}$ & ${ }^{t} \mathrm{Bu}$ & 28.8 & $65^{\mathrm{b}}$ \\
\hline
\end{tabular}

${ }^{a}$ Relative proportion of compounds in the mixture 10ca:10cb:10cc deduced from the ${ }^{31} \mathrm{P}-\mathrm{NMR}$ spectrum. ${ }^{b}$ Relative proportion of compounds in the mixture 10da:10db deduced from the ${ }^{31} \mathrm{P}$ NMR spectrum.

\section{Synthesis of pyrrolidones and pyridones}

The cyclization of the diphenylphosphoryl enamines $\mathbf{1 0}$ was achieved thermically. The course of the cyclocondensation was dependent on the reaction temperature and the solvent polarity. Thus, 4-diphenylphosphoryl-2-pyrrolidones $\mathbf{1 1}$ were obtained quantitatively by heating enamines $\mathbf{1 0}$ in acetonitrile at reflux for $12 \mathrm{~h},{ }^{19}$ except for $\mathbf{1 0 b}$ which was recovered unaltered (see below). Fortunately, the mixture of isomeric enamines with cyclohexyl, 10c, and $t$-butyl substituents, 10d, also lead to the same type of 2-pyrrolidone 11c-d with an $E$ exocyclic double bond (Scheme 3 ). The synthesis of the heterocycles can be performed in a one pot reaction by adding DMAD to a solution of the enamines 9 in acetonitrile and subsequent reflux of the reaction mixture without isolation of the intermediate product 10. The formation of a five-membered heterocycle and the $E$ configuration of the exocyclic double bond in position 3 were deduced from their NOE difference and HMBC spectra. ${ }^{6}$ Functionalized pyrrolidones are important compounds because of their biomedical properties. ${ }^{20}$ 


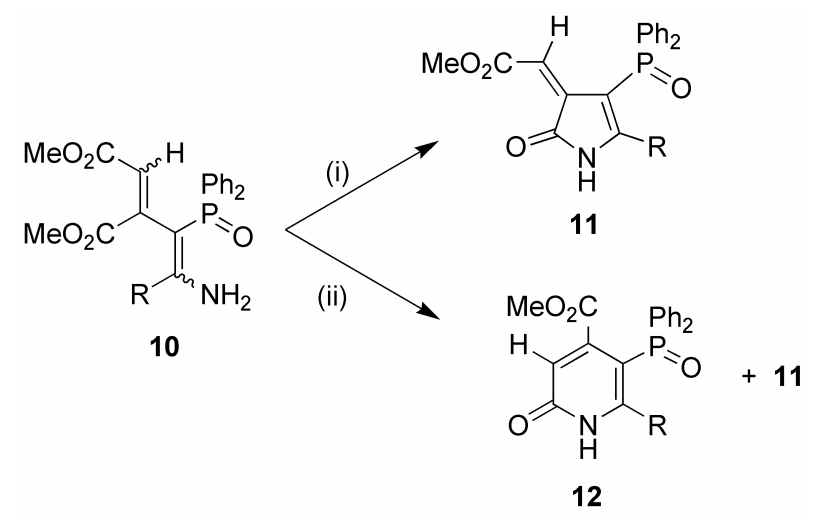

Scheme 3. (i) $\mathrm{CH}_{3} \mathrm{CN}$, reflux, $12 \mathrm{~h}$. (ii) Toluene, reflux, $12 \mathrm{~h}$ (for $\mathbf{1 0 b}$ four days or $24 \mathrm{~h}$ in refluxing xylene).

On the other hand, refluxing enamines 9 in toluene afforded mixtures of phosphorus substituted 2-pyrrolidones 11 and 2-pyridones 12, i.e., the diphenylphosphoryl derivatives 9 showed the same reactivity as the ( $N$-acyl)phosphazenyl series of enamines (Scheme 3 ). The heterocycles 11-12 were easily separated by fractional crystallization in hexane/chloroform or column chromatography (eluent: ethyl acetate). The exception in this case was 10d. The new product of the reaction was not the expected pyridone but the diphenylphosphoryl-3-pyrrolidone 13. The structural assignment was carried out based on the HMBC spectrum. ${ }^{21}$ A possible mechanism for the formation of $\mathbf{1 3}$ is shown in Scheme 4. The first step would consist in a proton displacement, either [1,5] from 10da or [1,3] from $10 \mathbf{d b}$, to generate an intermediate compound with an imino group conjugated with an electrophilic double bond. Intramolecular Michael addition of the imino nitrogen to this double bond would produce a reactive betaine, which undergoes a cyclocondensation reaction to yield a 3-pyrrolidone. Hydration of the $\mathrm{C}=\mathrm{N}$ linkage of this heterocycle during work up would lead to the final product $\mathbf{1 3}$.

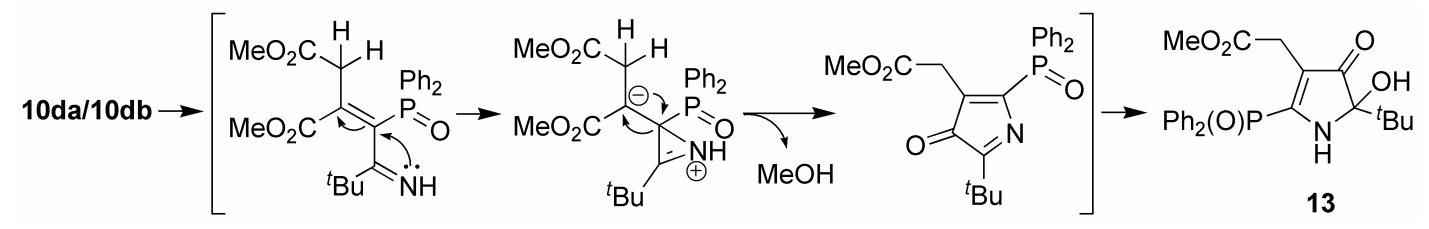

Scheme 4. Proposed mechanism for explaining the formation of the 5-diphenylphosphoryl-2hydroxy-3-pyrrolidone 13.

The cyclocondensation of $\mathbf{1 0 b}$ in refluxing toluene deserves some comments. Even after 48 $\mathrm{h}$ of heating the conversion was limited to $50 \%$ and the crude reaction mixture showed the presence of four products: two acyclic isomers of the starting enamine, 10ba and 10bb, and two heterocyclic, 11b and 12b, in a ratio 27:36:27:10, respectively. The reaction was completed by increasing the reaction time to four days. These conditions allowed to increase the yield of $\mathbf{1 1 b}$ 
to $70 \%$, while the relative ratio of the other three compounds $\mathbf{1 0 b a}: \mathbf{1 0 b b}: \mathbf{1 2 b}$ remained similar (11:14:5). The pyrrolidone $\mathbf{1 1 b}$ is very insoluble and precipitated from the reaction medium, which explained the increased yield and facilitated the isolation. The separation of $\mathbf{1 2 b}$ and the mixture 10ba/10bb was achieved by column chromatography using ethyl acetate as eluent. All compounds were identified following the procedure mentioned above for the other members of the series.

The proton spectrum of the mixture of enamines $\mathbf{1 0 b a} / \mathbf{1 0 b b}$ showed broad signals which narrowed upon cooling down to $-30{ }^{\circ} \mathrm{C}$ in $\mathrm{CDCl}_{3}$. At this temperature the magnitudes of ${ }^{3} J_{\mathrm{PC}}$ and the NOE enhancement observed indicated that the configuration of the double bonds of the dienic system was $Z, Z$ for both compounds. Consequently, they must be conformational isomers. Effectively, the proton spectrum of the mixture measured at $60{ }^{\circ} \mathrm{C}$ showed the expected set of signals for a single species although relatively broad because at this temperature the rate of exchange between the rotamers was still relatively slow on the NMR time scale. ${ }^{22}$ A new set of NOE difference spectra acquired in $\mathrm{C}_{6} \mathrm{D}_{6}$ allowed to identify the restricted rotation of the $o$-tolyl group as the origin of the duplication of the signals (Figure 4).
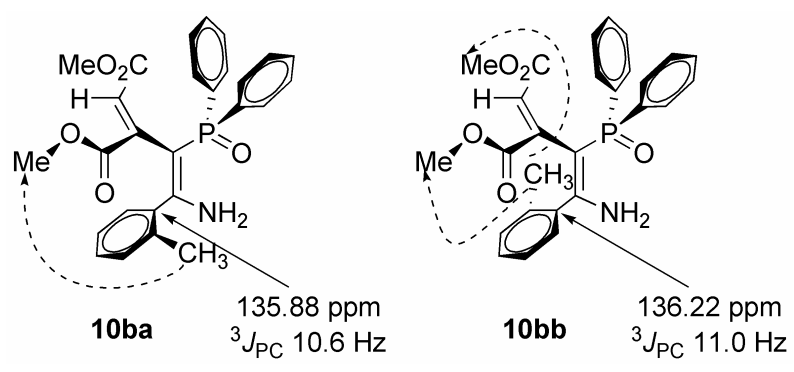

Figure 4. Selected NOEs for compounds $10 \mathrm{ba}$ and $\mathbf{1 0 b b}$ measured at $300.13 \mathrm{MHz}$ in $\mathrm{C}_{6} \mathrm{D}_{6}$.

The results above suggest that low polar solvents favored the formation of 2-pyridones vs. 2-pyrrolidones and that the inertia to the cyclocondensation derived from steric effects produced by the substituents on the enamine double bond might be overcome by heating at an appropriated temperature. Therefore, one may assume that the cyclization of $\mathbf{1 0 b}$ could be driven in a shorter time and with increased yield in pyridone by performing the reaction in refluxing xylene. In fact, under these conditions a conversion of $90 \%$ was reached in $24 \mathrm{~h}$. However, the yield of 2pyridones was not improved. A large number of natural and synthetic compounds containing the 2(1H)-pyridone structural fragment show valuable biological activities. ${ }^{23}$ Table 3 shows the heterocycles obtained by cyclocondensation of the enamines $\mathbf{1 0}$. 
Table 3. Mps, yields and ${ }^{31} \mathrm{P}$ chemical shifts for heterocycles 11-13 obtained by heating the enamines $\mathbf{1 0}$ in different solvents

\begin{tabular}{llllll}
\hline Product & $\mathrm{R}$ & M.p. $\left({ }^{\circ} \mathrm{C}\right)$ & $\delta^{31} \mathrm{P}(\mathrm{ppm})$ & Toluene & $\begin{array}{r}\text { Yield }(\%) \\
\text { Acetonitrile }\end{array}$ \\
\hline \hline 11a & $p-\mathrm{CH}_{3}-\mathrm{C}_{6} \mathrm{H}_{4}$ & 242 & 18.6 & 35 & $>97$ \\
11b & $o-\mathrm{CH}_{3}-\mathrm{C}_{6} \mathrm{H}_{4}$ & 302 & 20.1 & 70 & \\
11c & $\mathrm{C}_{6} \mathrm{H}_{11}$ & 248 & 21.9 & 60 & $>97$ \\
11d & ${ }^{t} \mathrm{Bu}$ & 193 & 21.9 & 67 & $>97$ \\
12a & $p-\mathrm{CH}_{3}-\mathrm{C}_{6} \mathrm{H}_{4}$ & 210 & 21.9 & 65 & \\
12b & $o-\mathrm{CH}_{3}-\mathrm{C}_{6} \mathrm{H}_{4}$ & 155 & 26.0 & 30 & \\
12c & $\mathrm{C}_{6} \mathrm{H}_{11}$ & 267 & 29.1 & 40 & \\
13 & ${ }^{t} \mathrm{Bu}$ & 201 & 29.6 & 33 & \\
\hline
\end{tabular}

In summary, new 4-diphenylphosphoryl-2-pyrrolidones and 5-diphenylphosphoryl-2pyridones have been synthesized by cyclocondensation of adequately functionalyzed enamines under reflux in acetonitrile or toluene. The required enamines have been obtained by addition of DMAD to simple $\beta$-diphenylphosphorylenamines. The stereoselectivity of this process depends on the substituents bonded to the enamine moiety. When the substituent is an aromatic ring the reaction is steroespecific whereas with aliphatic substituents a mixture of isomers is obtained. In this case also the isomers formed and their proportions depend on the substituent. The stereoselectivity found in the reaction with DMAD is, however, not essential for the heterocyclization process. Overall, the heterocycles can be obtained in a two step process using commercially available materials. It is also shown that bulky substituents promote alternative pathways for the reaction. Cyclocondensation of $o$-tolylsubstituted enamines was also achieved in refluxing xylene. Both solvents, toluene and xylene, led to 2-pyridone in similar yields but with the latter a higher conversion was obtained in a shorter time compared with the reaction in toluene. In refluxing toluene the $t$-butyl enamine afforded a 5-diphenylphosphoryl-2-hydroxy-3pyrrolidone instead of the expected 2-pyridone. A reasonable mechanism for the formation of this product was proposed.

\section{Experimental Section}

General Procedures. All reactions were carried out under an atmosphere of nitrogen using dried glassware. THF was distilled from sodium/benzophenone immediately prior use. Commercial reagents were purchased from Sigma-Aldrich Química S.A. and were distilled before use, except LiMe. Triphenylphosphine oxide was commercially available. TLC was performed on Merck plates with aluminium backing and silica gel $60 \mathrm{~F}_{254}$. For column chromatography silica gel 60 (40-63 $\mu \mathrm{m})$ from Scharlau was used. Melting points were recorded on a Büchi-Tottoli apparatus 
and are uncorrected. Infrared spectra were obtained in $\mathrm{KBr}$ pellets using a UNICAM Mattson 3020 FT spectrometer. Mass spectra were determined by electron impact on a Hewlett-Packard 5987A. Microanalysis were performed on a Perkin-Elmer 2400. NMR spectra were measured on a Bruker Avance 300DPX or Bruker 400 AMX spectrometer. Chemical shifts are referred to internal tetramethylsilane for ${ }^{1} \mathrm{H}$ and ${ }^{13} \mathrm{C}$, and to external $85 \% \mathrm{H}_{3} \mathrm{PO}_{4}$ for ${ }^{31} \mathrm{P}$. 2D NMR correlation spectra (COSY, NOESY, ROESY, HMQC and HMBC) were acquired using standard Bruker software and processing routines.

Compound characterization. Synthesis of $\boldsymbol{\beta}$-phosphorylenamines 9. $24 \mathrm{mmol}$ of LiMe were added dropwise to a solution of triphenylphosphine oxide $(20 \mathrm{mmol})$ in dry THF $(30 \mathrm{~mL})$ at $-30{ }^{\circ} \mathrm{C}$. After $2 \mathrm{~h}$ the temperature was lowered at $-70{ }^{\circ} \mathrm{C}$ and the desired nitrile $(20 \mathrm{mmol})$ dissolved in $5 \mathrm{~mL}$ THF was added. The reaction mixture was stirred for $8 \mathrm{~h}$ and allowed to reach room temperature. Addition of water $(25 \mathrm{~mL})$ followed by extraction with $\mathrm{CH}_{2} \mathrm{Cl}_{2}(3 \times 15 \mathrm{~mL})$ and solvent evaporation under vacuum afforded an oil. For compounds $9 \mathbf{a}, \mathbf{9 b}$, and $9 \mathbf{d}$, digestion of this oil in diethyl ether yielded the corresponding solid products. They were filtrated, dried and used without further purification.

(Z)-2-(Diphenylphosphoryl)-1-(4-methylphenyl)ethylenamine (9a). Yield 85\%. M.p. $102{ }^{\circ} \mathrm{C}$. IR $v\left(\mathrm{~cm}^{-1}\right) 3473,3320,1622,1545,1159 \mathrm{~cm}^{-1} .{ }^{1} \mathrm{H}-\mathrm{NMR}\left(300.13 \mathrm{MHz}, \mathrm{CDCl}_{3}\right) \delta(\mathrm{ppm}) 2.39(\mathrm{~s}$, $3 \mathrm{H}), 4.53\left(\mathrm{~d}, 1 \mathrm{H},{ }^{2} J_{\mathrm{PH}} 21.3 \mathrm{~Hz}\right), 5.82\left(\mathrm{~s}, 2 \mathrm{H}, \mathrm{NH}_{2}\right), 7.20$ (m, 2H, ArH), 7.50-7.80 (m, 12H, ArH). ${ }^{13} \mathrm{C}-\mathrm{NMR}\left(75.46 \mathrm{MHz}, \mathrm{CDCl}_{3}\right) \delta(\mathrm{ppm}) 21.13,77.63\left(\mathrm{~d},{ }^{1} J_{\mathrm{PC}} 104.6 \mathrm{~Hz}\right), 125.86,128.23\left(\mathrm{~d},{ }^{3} J_{\mathrm{PC}}\right.$ $11.7 \mathrm{~Hz}), 129.16,130.56\left(\mathrm{~d},{ }^{2} J_{\mathrm{PC}} 10.0 \mathrm{~Hz}\right), 131.00,135.75\left(\mathrm{~d},{ }^{1} J_{\mathrm{PC}} 104.4 \mathrm{~Hz}\right), 136.32\left(\mathrm{~d},{ }^{3} J_{\mathrm{PC}}\right.$ 15.2 Hz), 139.93, 161.58. ${ }^{31} \mathrm{P}-\mathrm{NMR}\left(121.4 \mathrm{MHz}, \mathrm{CDCl}_{3}\right) \delta(\mathrm{ppm}) 30.1 . \mathrm{MS}(\mathrm{EI}), \mathrm{m} / z: 333\left(\mathrm{M}^{+}\right.$, 13\%), 332 (66\%), 215 (24\%), 209 (72\%). Analysis: Calcd (\%) for $\mathrm{C}_{21} \mathrm{H}_{20} \mathrm{NOP}: \mathrm{C}, 75.67 ; \mathrm{H}$, $6.01 ; \mathrm{N}, 4.20$. Found: C, 75.63; H, 6.03; N, 4.21 .

(Z)-2-(Diphenylphosphoryl)-1-(2-methylphenyl)ethylenamine (9b). Yield 78\%. M.p. $127{ }^{\circ} \mathrm{C}$. IR $v\left(\mathrm{~cm}^{-1}\right) 3470,1611,1435,1119 .{ }^{1} \mathrm{H}-\mathrm{NMR}\left(300.13 \mathrm{MHz}, \mathrm{CDCl}_{3}\right) \delta(\mathrm{ppm}) 2.46(\mathrm{~s}, 3 \mathrm{H}), 4.28$ $\left(\mathrm{d}, 1 \mathrm{H},{ }^{2} J_{\mathrm{PH}} 23.12 \mathrm{~Hz}\right), 5.86\left(\mathrm{~s}, 2 \mathrm{H}, \mathrm{NH}_{2}\right), 7.18(\mathrm{~m}, 1 \mathrm{H}, \mathrm{ArH}), 7.21$ (m, 1H, ArH), 7.23 (m, 1H, $\mathrm{ArH}), 7.32$ (m, 1H, HAr), $7.50(\mathrm{~m}, 6 \mathrm{H}, \mathrm{ArH}), 7.75(\mathrm{~m}, 1 \mathrm{H}, \mathrm{ArH}) .{ }^{13} \mathrm{C}-\mathrm{NMR}(75.46 \mathrm{MHz}$, $\left.\mathrm{CDCl}_{3}\right) \delta(\mathrm{ppm}) 19.39,79.06\left(\mathrm{~d},{ }^{1} J_{\mathrm{PC}} 110.9 \mathrm{~Hz}\right), 125.70,127.70,128.29\left(\mathrm{~d},{ }^{3} J_{\mathrm{PC}} 11.9 \mathrm{~Hz}\right)$, 128.65, 130.44, $130.64\left(\mathrm{~d},{ }^{2} J_{\mathrm{PC}} 10.1 \mathrm{~Hz}\right), 131.27\left(\mathrm{~d},{ }^{4} J_{\mathrm{PC}} 2.4 \mathrm{~Hz}\right), 134.74,135.90\left(\mathrm{~d},{ }^{1} J_{\mathrm{PC}} 104.3\right.$ $\mathrm{Hz}), 139.96\left(\mathrm{~d},{ }^{3} J_{\mathrm{PC}} 4.6 \mathrm{~Hz}\right), 162.37 .{ }^{31} \mathrm{P}-\mathrm{NMR}\left(121.4 \mathrm{MHz}, \mathrm{DMSO}-d_{6}\right) \delta$ (ppm) 29.5. MS (EI), $m / z: 333\left(\mathrm{M}^{+}, 1.7 \%\right), 242(2 \%), 215(100 \%), 200(12 \%)$. Analysis: Calcd (\%) for $\mathrm{C}_{21} \mathrm{H}_{20} \mathrm{NOP}: \mathrm{C}$, 75.67; H, 6.01; N, 4.20. Found: C, 75.66; H, 6.03; N, 4.19 .

(Z)-1-Cyclohexyl-2-(diphenylphosphoryl)ethylenamine (9c). Yield 78\%. Oil. IR $v\left(\mathrm{~cm}^{-1}\right)$ 3399, 1638, 1578, 1118. ${ }^{1} \mathrm{H}-\mathrm{NMR}\left(300.13 \mathrm{MHz}, \mathrm{CDCl}_{3}\right) \delta(\mathrm{ppm})$ 0.90-1.90 (m, 1H), 4.10 (d, $\left.1 \mathrm{H},{ }^{2} J_{\mathrm{PH}} 22.7 \mathrm{~Hz}\right), 5.27$ (s, 2H, NH ), 7.30-7.50 (m, 4H, ArH). ${ }^{13} \mathrm{C}-\mathrm{NMR}\left(75.46 \mathrm{MHz}, \mathrm{CDCl}_{3}\right) \delta$ (ppm) 25.37, 25.72, 31.29, $46.17\left(\mathrm{~d},{ }^{3} J_{\mathrm{PC}} 13.0 \mathrm{~Hz}\right), 72.27\left(\mathrm{~d},{ }^{1} J_{\mathrm{PC}} 116.3 \mathrm{~Hz}\right), 127.62\left(\mathrm{~d},{ }^{3} J_{\mathrm{PC}} 12.7\right.$ $\mathrm{Hz}), 130.05\left(\mathrm{~d},{ }^{2} J_{\mathrm{PC}} 10.0 \mathrm{~Hz}\right), 130.26\left(\mathrm{~d},{ }^{4} J_{\mathrm{PC}} 2.1 \mathrm{~Hz}\right), 135.92\left(\mathrm{~d},{ }^{1} J_{\mathrm{PC}} 104.5 \mathrm{~Hz}\right), 169.24 .{ }^{31} \mathrm{P}-$ NMR (121.4 MHz, $\left.\mathrm{CDCl}_{3}\right) \delta(\mathrm{ppm})$ 30.4. MS (EI), m/z: $324\left(\mathrm{M}^{+}-1,26 \%\right), 215$ (40\%), 200 (89\%). Analysis: Calcd (\%) for $\mathrm{C}_{21} \mathrm{H}_{24} \mathrm{NOP}$ : C, 73.85; H, 7.38; N, 4.31. Found: C, 73.87; H, $7.38 ; \mathrm{N}, 4.33$. 
(1Z)-3,3-dimethyl-1-(diphenylphosphoryl)but-1-en-2-amine (9d). Yield 89\%. M.p. $141{ }^{\circ} \mathrm{C}$. IR $v\left(\mathrm{~cm}^{-1}\right)$ 3378, 3320, 1649, 1547, 1119. ${ }^{1} \mathrm{H}-\mathrm{NMR}\left(400.13 \mathrm{MHz}, \mathrm{CDCl}_{3}\right) \delta(\mathrm{ppm}) 1.20(\mathrm{~s}, 9 \mathrm{H})$, $4.23\left(\mathrm{~d}, 1 \mathrm{H},{ }^{2} J_{\mathrm{PH}} 21.8 \mathrm{~Hz}\right), 5.70$ (s, 2H, NH ), 7.45-7.55 (m, 4H, ArH), 7.70-7.80 (m, 2H, ArH). ${ }^{13} \mathrm{C}-\mathrm{NMR}\left(75.46 \mathrm{MHz}, \mathrm{CDCl}_{3}\right) \delta(\mathrm{ppm}) 29.60,37.54\left(\mathrm{~d},{ }^{3} J_{\mathrm{PC}} 12.2 \mathrm{~Hz}\right), 75.91\left(\mathrm{~d},{ }^{1} J_{\mathrm{PC}} 114.2 \mathrm{~Hz}\right)$, $128.91\left(\mathrm{~d},{ }^{3} J_{\mathrm{PC}} 12.0 \mathrm{~Hz}\right), 131.36\left(\mathrm{~d},{ }^{2} J_{\mathrm{PC}} 10.1 \mathrm{~Hz}\right), 131.59\left(\mathrm{~d},{ }^{4} J_{\mathrm{PC}} 1.9 \mathrm{~Hz}\right), 136.86\left(\mathrm{~d},{ }^{1} J_{\mathrm{PC}} 103.8\right.$ $\mathrm{Hz}$ ), 173.00. ${ }^{31} \mathrm{P}-\mathrm{NMR}\left(121.4 \mathrm{MHz}, \mathrm{CDCl}_{3}\right) \delta$ (ppm) 30.6. MS (EI), m/z: $299\left(\mathrm{M}^{+}, 20 \%\right), 242$ (54\%), 200 (100\%), 98 (84\%). Analysis: Calcd (\%) for $\mathrm{C}_{18} \mathrm{H}_{22} \mathrm{NOP}$ : C, 72.24; H, 7.36; N, 4.68. Found: C, 72.21; H, 7.35; N, 4.69 .

General procedure for the reaction of the phosphorylenamines 9 with DMAD. DMAD (5 mmol) was added to a solution of the corresponding compound 9 ( $5 \mathrm{mmol}$ ) in $\mathrm{CH}_{2} \mathrm{Cl}_{2}$, dried and freshly distilled under $N, N$-diethylaniline. The mixture was stirred at room temperature during 36 h. After in vacuo solvent evaporation compounds $\mathbf{1 0}$ were isolated by recristallization in hexanemethylene chloride.

Dimethyl (2E)-2-[(Z)-2-amino-2-(4-methylphenyl)-1-(diphenylphosphoryl)vinyl]but-2enedioato (10a). Yield >97\%. M.p. $90{ }^{\circ} \mathrm{C}$. IR $v\left(\mathrm{~cm}^{-1}\right) 3312,1722,1613,1435,1161 .{ }^{1} \mathrm{H}-\mathrm{NMR}$ $\left(300.13 \mathrm{MHz}, \mathrm{CDCl}_{3}\right) \delta(\mathrm{ppm}) 2.36(\mathrm{~s}, 3 \mathrm{H}), 3.10(\mathrm{~s}, 3 \mathrm{H}), 3.45(\mathrm{~s}, 3 \mathrm{H}), 5.34\left(\mathrm{~d}, 1 \mathrm{H},{ }^{4} J_{\mathrm{PH}} 2.8 \mathrm{~Hz}\right)$, 7.20 (m, 2H, HAr), 7.40-7.60 (m, 1H, HAr), 7.70-7.85 (m, 12H, HAr). ${ }^{13} \mathrm{C}-\mathrm{NMR}(75.46 \mathrm{MHz}$, $\left.\mathrm{CDCl}_{3}\right) \delta(\mathrm{ppm}) 21.29,51.30,51.67,88.54\left(\mathrm{~d},{ }^{1} J_{\mathrm{PC}} 107.4 \mathrm{~Hz}\right), 123.98\left(\mathrm{~d},{ }^{3} J_{\mathrm{PC}} 6.6 \mathrm{~Hz}\right), 128.30(\mathrm{~d}$, $\left.{ }^{3} J_{\mathrm{PC}} 12.2 \mathrm{~Hz}\right), 128.78,129.06,131.69,132.22\left(\mathrm{~d},{ }^{2} J_{\mathrm{PC}} 10.1 \mathrm{~Hz}\right), 132.62\left(\mathrm{~d},{ }^{1} J_{\mathrm{PC}} 105.3 \mathrm{~Hz}\right)$, $135.15\left(\mathrm{~d},{ }^{3} J_{\mathrm{PC}} 11.2 \mathrm{~Hz}\right), 140.34,144.69\left(\mathrm{~d},{ }^{2} J_{\mathrm{PC}} 9.6 \mathrm{~Hz}\right), 165.24,166.33\left(\mathrm{~d},{ }^{2} J_{\mathrm{PC}} 5.4 \mathrm{~Hz}\right), 168.06$ $\left(\mathrm{d},{ }^{3} J_{\mathrm{PC}} 5.2 \mathrm{~Hz}\right) .{ }^{31} \mathrm{P}-\mathrm{NMR}\left(121.4 \mathrm{MHz}, \mathrm{CDCl}_{3}\right) \delta(\mathrm{ppm}) 38.5$. MS (EI), $m / z: 475\left(\mathrm{M}^{+}, 3 \%\right), 416$ (20\%), 356 (23\%), 200 (86\%). Analysis: Calcd (\%) for $\mathrm{C}_{27} \mathrm{H}_{26} \mathrm{NO}_{5} \mathrm{P}: \mathrm{C}, 68.21 ; \mathrm{H}, 5.47$; N, 2.95. Found: C, 68.25; H, 5.46; N, 2.94.

Dimethyl (2E)-2-[(Z)-2-amino-2-(2-methylphenyl)-1-(diphenylphosphoryl)vinyl]but-2enedioato (10a). Yield >97\%. M.p. $108^{\circ} \mathrm{C}$. IR $v\left(\mathrm{~cm}^{-1}\right)$ 3410, 3308, 1718, 1523, 1436, 1167. ${ }^{1} \mathrm{H}-\mathrm{NMR}\left(400.13 \mathrm{MHz}, \mathrm{CDCl}_{3}\right) \delta(\mathrm{ppm}) 2.42(\mathrm{~s}, 3 \mathrm{H}), 3.06(\mathrm{~s}, 3 \mathrm{H}), 3.41(\mathrm{~s}, 3 \mathrm{H}), 5.24\left(\mathrm{~d}, 1 \mathrm{H},{ }^{4} J_{\mathrm{PH}}\right.$ $2.4 \mathrm{~Hz}$ ), 7.20 (m, 1H, HAr), 7.27 (m, 1H, HAr), 7.29 (m, 1H, HAr), 7.49-7.55 (m, 8H, HAr, $\mathrm{NH}_{2}$ ), 7.87-7.94 (m, 4H, HAr). ${ }^{13} \mathrm{C}-\mathrm{NMR}\left(100.61 \mathrm{MHz}, \mathrm{CDCl}_{3}\right) \delta$ (ppm) 19.47, 51.27, 51.79, $89.58\left(\mathrm{~d},{ }^{1} J_{\mathrm{PC}} 105.5\right), 122.90\left(\mathrm{~d},{ }^{3} J_{\mathrm{PC}} 5.9 \mathrm{~Hz}\right), 125.64,128.30\left(\mathrm{~d},{ }^{3} J_{\mathrm{PC}} 12.2 \mathrm{~Hz}\right), 129.24,129.46$, 130.36, $131.62\left(\mathrm{~d},{ }^{4} J_{\mathrm{PC}} 2.1 \mathrm{~Hz}\right), 131.96\left(\mathrm{~d},{ }^{2} J_{\mathrm{PC}} 9.9 \mathrm{~Hz}\right), 132.05\left(\mathrm{~d},{ }^{2} J_{\mathrm{PC}} 9.6 \mathrm{~Hz}\right), 132.77\left(\mathrm{~d},{ }^{1} J_{\mathrm{PC}}\right.$ $105.1 \mathrm{~Hz}), 133.11\left(\mathrm{~d},{ }^{1} J_{\mathrm{PC}} 105.2 \mathrm{~Hz}\right), 135.90,137.01$ (d, $\left.{ }^{3} J_{\mathrm{PC}} 11.0 \mathrm{~Hz}\right), 143.93\left(\mathrm{~d},{ }^{2} J_{\mathrm{PC}} 9.7 \mathrm{~Hz}\right)$, $165.09\left(\mathrm{~d},{ }^{4} J_{\mathrm{PC}} 1.6 \mathrm{~Hz}\right), 165.49$ (d, $\left.{ }^{2} J_{\mathrm{PC}} 5.4 \mathrm{~Hz}\right), 167.93$ (d, $\left.{ }^{3} J_{\mathrm{PC}} 6.6 \mathrm{~Hz}\right) .{ }^{31} \mathrm{P}-\mathrm{NMR}(121.4 \mathrm{MHz}$, DMSO- $\left.d_{6}\right) \delta(\mathrm{ppm})$ 37.5. MS (EI), m/z: $475\left(\mathrm{M}^{+}, 2 \%\right), 384(14 \%), 320(2 \%), 242(3 \%), 200$ (70\%). Analysis: Calcd (\%) for $\mathrm{C}_{27} \mathrm{H}_{26} \mathrm{NO}_{5} \mathrm{P}: \mathrm{C}, 68.21 ; \mathrm{H}, 5.47$; N, 2.95. Found: C, 68.18; H, $5.48 ; \mathrm{N}, 2.94$.

Dimethyl (2Z)-2-[(Z)-2-amino-2-(2-methylphenyl)-1-(diphenylphosphoryl)vinyl]but-2enedioato (10ba and 10bb). These compounds are two conformers that were obtained as a 43:57 mixture when the enamine 10b was heated in refluxing toluene. The solid mixture (10ba and $\mathbf{1 0 b b}$ ) was isolated and purified form the reaction crude that also contain compounds $\mathbf{1 1 b}$ and $\mathbf{1 2 b}$ by means of column chromatography using a mixture of ethyl acetate and methanol 
(1.1) as eluent. M.p. $78^{\circ} \mathrm{C}$. IR $v\left(\mathrm{~cm}^{-1}\right) 3422,1718,1647,1628,1437,1113,{ }^{1} \mathrm{H}-\mathrm{NMR}(400.13$ $\mathrm{MHz}, \mathrm{CDCl}_{3}$, T: $\left.240 \mathrm{~K}\right) \delta(\mathrm{ppm}) 2.26(\mathrm{~s}, 3 \mathrm{H}, \mathbf{1 0 b a}), 2.32(\mathrm{~s}, 3 \mathrm{H}, \mathbf{1 0 b b}), 3.30$ (s, 3H, 10bb), 3.36 (s, 3H, 10ba), 3.52 (s, 3H, 10ba), 3.53 (s, 3H, 10bb), $5.48\left(\mathrm{~s}, 2 \mathrm{H}, \mathrm{NH}_{2}, \mathbf{1 0 b b}\right), 5.55\left(\mathrm{~s}, 2 \mathrm{H}, \mathrm{NH}_{2}\right.$, 10ba), $6.03\left(\mathrm{~d}, 1 \mathrm{H},{ }^{4} J_{\mathrm{PH}} 1.8 \mathrm{~Hz}, \mathbf{1 0 b a}\right), 6.13\left(\mathrm{~d}, 1 \mathrm{H},{ }^{4} J_{\mathrm{PH}} 2.2 \mathrm{~Hz}, \mathbf{1 0 b b}\right), 7.00-7.50$ (m, 8H, HAr), 7.60-7.70 (m, 12H, HAr), 8.00-8.10 (m, 8H, HAr). ${ }^{13} \mathrm{C}-\mathrm{NMR}\left(100.61 \mathrm{MHz}, \mathrm{CDCl}_{3}, \mathrm{~T}: 240 \mathrm{~K}\right) \delta$ (ppm) 19.34 (10ba), 19.46 (10bb), 51.58 (10bb), 52.55 (10ba), 90.28 (d, $\left.{ }^{1} J_{\mathrm{PC}} 108.6 \mathrm{~Hz}, \mathbf{1 0 b a}\right)$, $90.73\left(\mathrm{~d},{ }^{1} J_{\mathrm{PC}} 107.9 \mathrm{~Hz}, \mathbf{1 0 b b}\right), 125.09$ (10ba), 125.27 (10bb), 127.37 (d, $\left.{ }^{3} J_{\mathrm{PC}} 12.4 \mathrm{~Hz},\right), 127.57$ $\left(\mathrm{d},{ }^{3} J_{\mathrm{PC}} 13.0 \mathrm{~Hz}\right), 127.99\left(\mathrm{~d},{ }^{3} J_{\mathrm{PC}} 6.8 \mathrm{~Hz}\right), 128.11\left(\mathrm{~d},{ }^{3} J_{\mathrm{PC}} 7.5 \mathrm{~Hz}\right), 128.95\left(\mathrm{~d},{ }^{3} J_{\mathrm{PC}} 6.5 \mathrm{~Hz}\right)$, 128.38, 130.02, 130.39, $131.14\left(\mathrm{~d},{ }^{3} J_{\mathrm{PC}} 12.4 \mathrm{~Hz}\right), 131.51\left(\mathrm{~d},{ }^{2} J_{\mathrm{PC}} 10.1 \mathrm{~Hz}\right), 131.60\left(\mathrm{~d},{ }^{2} J_{\mathrm{PC}} 8.3\right.$ $\mathrm{Hz}), 131.75$ (d, $\left.{ }^{1} J_{\mathrm{PC}} 90.3 \mathrm{~Hz}\right), 132.40$ (d, $\left.{ }^{1} J_{\mathrm{PC}} 106.2 \mathrm{~Hz}, \mathbf{1 0 b a}\right), 134.43$ (d, $\left.{ }^{1} J_{\mathrm{PC}} 104.7 \mathrm{~Hz}, \mathbf{1 0 b b}\right)$, $134.48\left(\mathrm{~d},{ }^{1} J_{\mathrm{PC}} 104.7 \mathrm{~Hz}, \mathbf{1 0 b b}\right), 134.99,135.88$ (d, $\left.{ }^{3} J_{\mathrm{PC}} 10.6 \mathrm{~Hz}, \mathbf{1 0 b a}\right), 136.08,136.22\left(\mathrm{~d},{ }^{3} J_{\mathrm{PC}}\right.$ $10.6 \mathrm{~Hz}, \mathbf{1 0 b b}), 141.75$ (d, $\left.{ }^{2} J_{\mathrm{PC}} 9.7 \mathrm{~Hz}, \mathbf{1 0 b a}\right), 142.09$ (d, $\left.{ }^{2} J_{\mathrm{PC}} 9.7 \mathrm{~Hz}, \mathbf{1 0 b b}\right), 159.87$ (d, ${ }^{2} J_{\mathrm{PC}} 3.4$ $\mathrm{Hz}, \mathbf{1 0 b a}), 160.07$ (d, $\left.{ }^{2} J_{\mathrm{PC}} 3.6 \mathrm{~Hz}, \mathbf{1 0 b b}\right), 164.87$ (10bb), 165.24 (10ba), 167.96 (d, ${ }^{3} J_{\mathrm{PC}} 5.0 \mathrm{~Hz}$, 10ba), 167.96 (d, $\left.{ }^{3} J_{\mathrm{PC}} 5.0 \mathrm{~Hz}, \mathbf{1 0 b b}\right) .{ }^{31} \mathrm{P}-\mathrm{NMR}\left(121.4 \mathrm{MHz}, \mathrm{CDCl}_{3}\right) \delta$ (ppm) 28.40 (10ba), 29.00 (10bb).

Dimethyl (2E)-2-[(Z)-2-amino-2-cyclohexyl-1-(diphenylphosphoryl)vinyl]but-2-enedioato (10ca) and Dimethyl (2Z)-2-[(E)-2-amino-2-cyclohexyl-1-(diphenylphosphoryl)vinyl]but-2enedioato (10cb). Compounds 10ca and 10cb cannot be separated from the mixture 10ca:10cb:10cc (80:10:10). 10ca. ${ }^{1} \mathrm{H}-\mathrm{NMR}\left(300.13 \mathrm{MHz}, \mathrm{CDCl}_{3}\right) \delta(\mathrm{ppm})$ 0.90-1.90 (m, 10H), $2.77(\mathrm{~m}, 1 \mathrm{H}), 3.49(\mathrm{~s}, 3 \mathrm{H}), 3.60(\mathrm{~s}, 3 \mathrm{H}), 5.45\left(\mathrm{~d}, 1 \mathrm{H},{ }^{4} J_{\mathrm{PH}} 3.3 \mathrm{~Hz}\right), 7.45-7.90(\mathrm{~m}, 12 \mathrm{H}, \mathrm{HAr}$, $\left.\mathrm{NH}_{2}\right) .{ }^{13} \mathrm{C}-\mathrm{NMR}\left(75.13 \mathrm{MHz}, \mathrm{CDCl}_{3}\right) \delta(\mathrm{ppm}) 25.75,25.90,31.14,43.23\left(\mathrm{~d},{ }^{3} J_{\mathrm{PC}} 8.9 \mathrm{~Hz}\right), 51.61$, $51.85,84.64\left(\mathrm{~d},{ }^{1} J_{\mathrm{PC}} 106.4 \mathrm{~Hz}\right), 127.18\left(\mathrm{~d},{ }^{3} J_{\mathrm{PC}} 6.5 \mathrm{~Hz}\right), 128.00\left(\mathrm{~d},{ }^{3} J_{\mathrm{PC}} 12.4 \mathrm{~Hz}\right), 131.06,131.42$ $\left(\mathrm{d},{ }^{2} J_{\mathrm{PC}} 6.8 \mathrm{~Hz}\right), 131.65\left(\mathrm{~d},{ }^{2} J_{\mathrm{PC}} 9.5 \mathrm{~Hz}\right), 133.15\left(\mathrm{~d},{ }^{1} J_{\mathrm{PC}} 98.1 \mathrm{~Hz}\right), 143.95\left(\mathrm{~d},{ }^{2} J_{\mathrm{PC}} 9.6 \mathrm{~Hz}\right), 165.05$ $\left(\mathrm{d},{ }^{4} J_{\mathrm{PC}} 2.2 \mathrm{~Hz}\right), 168.36\left(\mathrm{~d},{ }^{2} J_{\mathrm{PC}} 3.4 \mathrm{~Hz}\right), 168.89\left(\mathrm{~d},{ }^{3} J_{\mathrm{PC}} 3.0 \mathrm{~Hz}\right) .{ }^{31} \mathrm{P}-\mathrm{NMR}\left(121.4 \mathrm{MHz}, \mathrm{CDCl}_{3}\right)$ $\delta(\mathrm{ppm}) 36.40$. 10cb. ${ }^{1} \mathrm{H}-\mathrm{NMR}\left(300.13 \mathrm{MHz}, \mathrm{CDCl}_{3}\right) \delta(\mathrm{ppm})$ 0.90-1.90 (m, 10H), $2.85(\mathrm{~m}, 1 \mathrm{H})$, $3.62(\mathrm{~s}, 3 \mathrm{H}), 3.84(\mathrm{~s}, 3 \mathrm{H}), 4.25\left(\mathrm{~d}, 1 \mathrm{H},{ }^{4} \mathrm{~J}_{\mathrm{PH}} 1.4 \mathrm{~Hz}\right), 7.40-8.1$ (m, 10H, HAr). ${ }^{13} \mathrm{C}-\mathrm{NMR}(75.13$ $\left.\mathrm{MHz}, \mathrm{CDCl}_{3}\right) \delta(\mathrm{ppm}) 25.74,25.75,25.78,30.27,42.15\left(\mathrm{~d},{ }^{3} J_{\mathrm{PC}} 6.3 \mathrm{~Hz}\right), 52.02,52.55,91.49$ (d, $\left.{ }^{1} J_{\mathrm{PC}} 126.8 \mathrm{~Hz}\right), 127.77\left(\mathrm{~d},{ }^{3} J_{\mathrm{PC}} 12.0 \mathrm{~Hz}\right), 127.84\left(\mathrm{~d},{ }^{3} J_{\mathrm{PC}} 12.1 \mathrm{~Hz}\right), 130.76\left(\mathrm{~d},{ }^{4} J_{\mathrm{PC}} 3.6 \mathrm{~Hz}\right)$, $130.82\left(\mathrm{~d},{ }^{4} J_{\mathrm{PC}} 3.6 \mathrm{~Hz}\right), 131.51\left(\mathrm{~d},{ }^{3} J_{\mathrm{PC}} 2.8 \mathrm{~Hz}\right), 131.65\left(\mathrm{~d},{ }^{2} J_{\mathrm{PC}} 9.7 \mathrm{~Hz}\right), 132.05\left(\mathrm{~d},{ }^{2} J_{\mathrm{PC}} 9.1 \mathrm{~Hz}\right)$, $135.36\left(\mathrm{~d},{ }^{1} J_{\mathrm{PC}} 105.7 \mathrm{~Hz}\right), 135.76\left(\mathrm{~d},{ }^{1} J_{\mathrm{PC}} 106.8 \mathrm{~Hz}\right), 140.50\left(\mathrm{~d},{ }^{2} J_{\mathrm{PC}} 9.7 \mathrm{~Hz}\right), 163.32\left(\mathrm{~d},{ }^{2} J_{\mathrm{PC}} 14.7\right.$ $\mathrm{Hz}), 165.32\left(\mathrm{~d},{ }^{4} J_{\mathrm{PC}} 2.2 \mathrm{~Hz}\right), 167.04\left(\mathrm{~d},{ }^{3} J_{\mathrm{PC}} 3.6 \mathrm{~Hz}\right) .{ }^{31} \mathrm{P}-\mathrm{NMR}\left(121.4 \mathrm{MHz}, \mathrm{CDCl}_{3}\right) \delta(\mathrm{ppm})$ 23.30 .

Dimethyl (2Z)-2-[(Z)-2-amino-2-cyclohexyl-1-(diphenylphosphoryl)vinyl]but-2-enedioato (10cc). Solid isolated from the mixture 10ca:10cb:10cc $(80: 10: 10)$ on standing the reaction crude in $\mathrm{CHCl}_{3}$ solution. M.p. $186^{\circ} \mathrm{C}$. IR v $\left(\mathrm{cm}^{-1}\right)$ 3440, 3347, 1726, $17071640,1450,1161 .{ }^{1} \mathrm{H}-\mathrm{NMR}$ $\left(300.13 \mathrm{MHz}, \mathrm{CDCl}_{3}\right) \delta(\mathrm{ppm})$ 0.90-1.90 (m, 10H), $2.40(\mathrm{~m}, 1 \mathrm{H}), 3.52(\mathrm{~s}, 3 \mathrm{H}), 3.62(\mathrm{~s}, 3 \mathrm{H}), 5.74$ $\left(\mathrm{s}, 2 \mathrm{H}, \mathrm{NH}_{2}\right), 6.68\left(\mathrm{~d}, 1 \mathrm{H},{ }^{4} J_{\mathrm{PH}} 1.5 \mathrm{~Hz}\right), 7.40-7.80$ (m, 10H, HAr). ${ }^{13} \mathrm{C}-\mathrm{NMR}(100.61 \mathrm{MHz}$, $\left.\mathrm{CDCl}_{3}\right) \delta(\mathrm{ppm}) 25.90,26.01,26.33,30.15,31.10,43.44\left(\mathrm{~d},{ }^{3} J_{\mathrm{PC}} 8.9 \mathrm{~Hz}\right), 51.59,52.30,84.64(\mathrm{~d}$, $\left.{ }^{1} J_{\mathrm{PC}} 106.4 \mathrm{~Hz}\right), 127.68\left(\mathrm{~d},{ }^{3} J_{\mathrm{PC}} 12.0 \mathrm{~Hz}\right), 127.85\left(\mathrm{~d},{ }^{3} J_{\mathrm{PC}} 12.0 \mathrm{~Hz}\right), 130.79\left(\mathrm{~d},{ }^{3} J_{\mathrm{PC}} 2.6 \mathrm{~Hz}\right)$, $131.21\left(\mathrm{~d},{ }^{4} J_{\mathrm{PC}} 2.6 \mathrm{~Hz}\right), 131.26\left(\mathrm{~d},{ }^{4} J_{\mathrm{PC}} 2.8 \mathrm{~Hz}\right), 131.98\left(\mathrm{~d},{ }^{2} J_{\mathrm{PC}} 10.2 \mathrm{~Hz}\right), 132.38\left(\mathrm{~d},{ }^{2} J_{\mathrm{PC}} 10.2\right.$ 
$\mathrm{Hz}), 133.05\left(\mathrm{~d},{ }^{1} J_{\mathrm{PC}} 103.7 \mathrm{~Hz}\right), 133.21\left(\mathrm{~d},{ }^{1} J_{\mathrm{PC}} 105.1 \mathrm{~Hz}\right), 140.79\left(\mathrm{~d},{ }^{2} J_{\mathrm{PC}} 10.0 \mathrm{~Hz}\right), 165.91(\mathrm{~d}$, $\left.{ }^{2} J_{\mathrm{PC}} 1.9 \mathrm{~Hz}\right), 165.96\left(\mathrm{~d},{ }^{4} J_{\mathrm{PC}} 1.6 \mathrm{~Hz}\right), 167.69\left(\mathrm{~d},{ }^{3} J_{\mathrm{PC}} 2.2 \mathrm{~Hz}\right) .{ }^{31} \mathrm{P}-\mathrm{NMR}\left(121.4 \mathrm{MHz}, \mathrm{CDCl}_{3}\right) \delta$ (ppm) 31.40. MS (EI), m/z: $467\left(\mathrm{M}^{+}, 2 \%\right), 435$ (7\%), 376 (3\%), 200 (100\%). Analysis: Calcd (\%) for $\mathrm{C}_{26} \mathrm{H}_{30} \mathrm{NO}_{5} \mathrm{P}: \mathrm{C}, 66.80 ; \mathrm{H}, 6.42 ; \mathrm{N}, 3.00$. Found: C, 66.85; H, 6.40; N, 2.99.

Dimethyl (2E)-2-[(1Z)-2-amino-3,3-dimethyl-1-(diphenylphosphoryl)but-1-en-1-yl]but-2enedioato (10da) and dimethyl (2E)-2-[3,3-dimethyl-2-imino-1(diphenylphosphoryl)butyl]but-2-enedioato (10db). 10da:10db Isolated as 35:65 mixture. The NMR spectra for 10db were measured at $213 \mathrm{~K}$, thus the two species 10dba and 10dbb showed in Fig. 3 could be characterized. Oil. IR $v\left(\mathrm{~cm}^{-1}\right)$ 3460, 1728, 1439, 1269, 1199. 10da. ${ }^{1} \mathrm{H}-\mathrm{NMR}$ $\left(300.13 \mathrm{MHz}, \mathrm{CDCl}_{3}\right) \delta(\mathrm{ppm}) 1.21(\mathrm{~s}, 9 \mathrm{H}), 3.22(\mathrm{~s}, 3 \mathrm{H}), 3.54(\mathrm{~s}, 3 \mathrm{H}), 5.91\left(\mathrm{~d}, 1 \mathrm{H},{ }^{4} J_{\mathrm{PH}} 4.5 \mathrm{~Hz}\right)$, 7.20-7.40 (m, 6H, HAr), 7.70-7.80 (m, 6H, HAr, $\left.\mathrm{NH}_{2}\right) .{ }^{13} \mathrm{C}-\mathrm{NMR}\left(100.61 \mathrm{MHz}, \mathrm{CDCl}_{3}\right) \delta(\mathrm{ppm})$ 27.06, $39.06\left(\mathrm{~d},{ }^{3} J_{\mathrm{PC}} 10.2 \mathrm{~Hz}\right), 51.52,51.54,86.30\left(\mathrm{~d},{ }^{1} J_{\mathrm{PC}} 104.4 \mathrm{~Hz}\right), 128.15\left(\mathrm{~d},{ }^{3} J_{\mathrm{PC}} 11.4 \mathrm{~Hz}\right)$, $128.81\left(\mathrm{~d},{ }^{2} J_{\mathrm{PC}} 8.2 \mathrm{~Hz}\right), 131.81\left(\mathrm{~d},{ }^{4} J_{\mathrm{PC}} 2.7 \mathrm{~Hz}\right), 134.40\left(\mathrm{~d},{ }^{3} J_{\mathrm{PC}} 8.2 \mathrm{~Hz}\right), 138.10\left(\mathrm{~d},{ }^{2} J_{\mathrm{PC}} 7.7 \mathrm{~Hz}\right)$, $165.85\left(\mathrm{~d},{ }^{4} J_{\mathrm{PC}} 2.5 \mathrm{~Hz}\right), 166.49$ (d, $\left.{ }^{3} J_{\mathrm{PC}} 2.4 \mathrm{~Hz}\right), 169.75\left(\mathrm{~d},{ }^{2} J_{\mathrm{PC}} 2.4 \mathrm{~Hz}\right) .{ }^{31} \mathrm{P}-\mathrm{NMR}(121.4 \mathrm{MHz}$, $\left.\mathrm{CDCl}_{3}\right) \delta(\mathrm{ppm})$ 37.20. 10dba. ${ }^{1} \mathrm{H}-\mathrm{NMR}\left(300.13 \mathrm{MHz}, \mathrm{CDCl}_{3}\right.$, T: $\left.213 \mathrm{~K}\right) \delta(\mathrm{ppm}) 0.76(\mathrm{~s}, 9 \mathrm{H})$, $3.13(\mathrm{~s}, 3 \mathrm{H}), 3.60(\mathrm{~s}, 3 \mathrm{H}), 4.60\left(\mathrm{~d}, 1 \mathrm{H},{ }^{2} J_{\mathrm{PH}} 8.1 \mathrm{~Hz}\right), 6.39\left(\mathrm{~d}, 1 \mathrm{H},{ }^{4} J_{\mathrm{PH}} 4.0 \mathrm{~Hz}\right), 7.37-7.53(\mathrm{~m}, 6 \mathrm{H}$, HAr), 7.67-7.90 (m, 4H, HAr), 10.98 (s, 1H, NH). ${ }^{13} \mathrm{C}-\mathrm{NMR}\left(100.61 \mathrm{MHz}, \mathrm{CDCl}_{3}, \mathrm{~T}: 213 \mathrm{~K}\right) \delta$ (ppm) 26.33, 41.35 (d, $\left.{ }^{3} J_{\mathrm{PC}} 3.3 \mathrm{~Hz}\right), 44.94\left(\mathrm{~d},{ }^{1} J_{\mathrm{PC}} 60.7 \mathrm{~Hz}\right), 52.11,52.21,126.47\left(\mathrm{~d},{ }^{3} J_{\mathrm{PC}} 6.8\right.$ $\mathrm{Hz}), 127.30-128.34$ (d, $\left.{ }^{3} J_{\mathrm{PC}} 11.9-13.2 \mathrm{~Hz}\right), 127.80-131.50,130.58-132.65$ (d, $\left.{ }^{2} J_{\mathrm{PC}} 8.4-8.6 \mathrm{~Hz}\right)$, $137.49\left(\mathrm{~d},{ }^{2} J_{\mathrm{PC}} 7.4 \mathrm{~Hz}\right), 165.32\left(\mathrm{~d},{ }^{4} J_{\mathrm{PC}} 2.9 \mathrm{~Hz}\right), 167.45,180.61\left(\mathrm{~d},{ }^{2} J_{\mathrm{PC}} 2.5 \mathrm{~Hz}\right) .{ }^{31} \mathrm{P}-\mathrm{NMR}(121.4$ $\mathrm{MHz}, \mathrm{CDCl}_{3}$, T: $\left.213 \mathrm{~K}\right) \delta(\mathrm{ppm})$ 28.90. 10dbb. ${ }^{1} \mathrm{H}-\mathrm{NMR}\left(300.13 \mathrm{MHz}, \mathrm{CDCl}_{3}, \mathrm{~T}: 213 \mathrm{~K}\right) \delta$ (ppm) $0.86(\mathrm{~s}, 9 \mathrm{H}), 3.06(\mathrm{~s}, 3 \mathrm{H}), 3.56(\mathrm{~s}, 3 \mathrm{H}), 4.81\left(\mathrm{~d}, 1 \mathrm{H},{ }^{2} J_{\mathrm{PH}} 10.3 \mathrm{~Hz}\right), 6.66\left(\mathrm{~d}, 1 \mathrm{H},{ }^{4} J_{\mathrm{PH}} 4.4\right.$ $\mathrm{Hz}$ ), 7.37-7.53 (m, 6H, HAr), 7.67-7.90 (m, 4H, HAr), 9.85 (s, 1H, NH). ${ }^{13} \mathrm{C}-\mathrm{NMR}(100.61$ $\left.\mathrm{MHz}, \mathrm{CDCl}_{3}, \mathrm{~T}: 213 \mathrm{~K}\right) \delta(\mathrm{ppm}) 25.81,41.91\left(\mathrm{~d},{ }^{3} J_{\mathrm{PC}} 2.8 \mathrm{~Hz}\right), 46.48\left(\mathrm{~d},{ }^{1} J_{\mathrm{PC}} 61.2 \mathrm{~Hz}\right), 52.11$, $52.33,125.73\left(\mathrm{~d},{ }^{3} J_{\mathrm{PC}} 6.2 \mathrm{~Hz}\right), 127.30-128.34$ (d, $\left.{ }^{3} J_{\mathrm{PC}} 11.9-13.2 \mathrm{~Hz}\right), 127.80-131.50,130.58-$ $132.65\left(\mathrm{~d},{ }^{2} J_{\mathrm{PC}} 8.4-8.6 \mathrm{~Hz}\right), 138.58\left(\mathrm{~d},{ }^{2} J_{\mathrm{PC}} 6.6 \mathrm{~Hz}\right), 166.20,168.15,182.73\left(\mathrm{~d},{ }^{2} J_{\mathrm{PC}} 5.1 \mathrm{~Hz}\right) .{ }^{31} \mathrm{P}-$ NMR (121.4 MHz, $\mathrm{CDCl}_{3}$, T: $\left.213 \mathrm{~K}\right) \delta(\mathrm{ppm}) 27.70$.

General procedure for the synthesis of 2-pyrrolidones 11. A solution of compound 10 (5 mmol) in dry $\mathrm{CH}_{3} \mathrm{CN}$ was heated $12 \mathrm{~h}$ at reflux. Evaporation of the mixture under reduced pressure afforded a crude solid, which was recrystallized from hexane-dichloromethane to give compounds 11a, 11b and 11d. Compound 11b was only obtained using dry toluene (or xylene) as solvent.

Mehtyl (2E)-[5-(4-methylphenyl)-2-oxo-4-(diphenylphosphoryl)-1,2-dihydro-3H-pyrrol-3ylidene] acetate (11a). Yield $>97 \%$. M.p. $242{ }^{\circ} \mathrm{C}$. IR $v\left(\mathrm{~cm}^{-1}\right) 3492,1728,1685,1435,1157 .{ }^{1} \mathrm{H}-$ NMR (300.13 MHz, $\left.\mathrm{CDCl}_{3}\right) \delta(\mathrm{ppm}) 2.26(\mathrm{~s}, 3 \mathrm{H}), 3.39$ (s, 3H), 5.82 (s, 1H), 7.00 (m, 2H, HAr), 7.33 (m, 2H, HAr), 7.30-7.70 (m, 10H, HAr). ${ }^{13} \mathrm{C}-\mathrm{NMR}\left(75.46 \mathrm{MHz}, \mathrm{CDCl}_{3}\right) \delta$ (ppm) 20.90, $52.13,99.05\left(\mathrm{~d},{ }^{1} J_{\mathrm{PC}} 123.4 \mathrm{~Hz}\right), 124.49,125.61,128.19,128.61,128.58\left(\mathrm{~d},{ }^{3} J_{\mathrm{PC}} 13.7 \mathrm{~Hz}\right), 131.23$ $\left(\mathrm{d},{ }^{2} J_{\mathrm{PC}} 10.0 \mathrm{~Hz}\right), 131.53\left(\mathrm{~d},{ }^{4} J_{\mathrm{PC}} 2.4 \mathrm{~Hz}\right), 133.95\left(\mathrm{~d},{ }^{1} J_{\mathrm{PC}} 107.4 \mathrm{~Hz}\right), 136.20\left(\mathrm{~d},{ }^{2} J_{\mathrm{PC}} 7.6 \mathrm{~Hz}\right)$, 140.48, 158.85 (d, $\left.{ }^{2} J_{\mathrm{PC}} 13.4 \mathrm{~Hz}\right), 166.35,166.90$ (d, $\left.{ }^{3} J_{\mathrm{PC}} 11.5 \mathrm{~Hz}\right) .{ }^{31} \mathrm{P}-\mathrm{NMR}(121.4 \mathrm{MHz}$, 
$\left.\mathrm{CDCl}_{3}\right) \delta(\mathrm{ppm})$ 18.60. MS (EI), m/z: $443\left(\mathrm{M}^{+}, 3 \%\right), 383$ (39\%), 305 (13\%). Analysis: Calcd (\%) for $\mathrm{C}_{26} \mathrm{H}_{22} \mathrm{NO}_{4} \mathrm{P}: \mathrm{C}, 70.43 ; \mathrm{H}, 4.97 ; \mathrm{N}, 3.16$. Found: C, 70.46; H, 4.96; N, 3.15.

Mehtyl (2E)-[5-(2-methylphenyl)-2-oxo-4-(diphenylphosphoryl)-1,2-dihydro-3H-pyrrol-3ylidene] acetate (11b). Yield 70\%. M.p. $302{ }^{\circ} \mathrm{C}$. IR $v\left(\mathrm{~cm}^{-1}\right)$ 3151, 1728, 1626, 1177. ${ }^{1} \mathrm{H}-\mathrm{NMR}$ $\left(300.13 \mathrm{MHz}, \mathrm{CDCl}_{3}\right) \delta(\mathrm{ppm}) 2.10(\mathrm{~s}, 3 \mathrm{H}), 3.81(\mathrm{~s}, 3 \mathrm{H}), 6.52(\mathrm{~s}, 1 \mathrm{H}), 6.85$ (m, 2H, HAr), 6.90 (m, 1H, HAr), 7.03 (m, 1H, HAr), 7.25-7.40 (m, 6H, HAr), 7.50-7.55 (m, 2H, HAr), 7.90 (s, 1H, $\mathrm{NH}) .{ }^{13} \mathrm{C}-\mathrm{NMR}\left(75.46 \mathrm{MHz}, \mathrm{DMSO}-d_{6}\right.$, T: $\left.393 \mathrm{~K}\right) \delta(\mathrm{ppm}) 18.34,50.85,100.84\left(\mathrm{~d},{ }^{1} J_{\mathrm{PC}} 123.0\right.$ $\mathrm{Hz}), 124.23,124.53,127.39\left(\mathrm{~d},{ }^{3} J_{\mathrm{PC}} 12.3 \mathrm{~Hz}\right), 128.33,128.74,128.88,128.94,130.36\left(\mathrm{~d},{ }^{2} J_{\mathrm{PC}}\right.$ $10.5 \mathrm{~Hz}), 130.66\left(\mathrm{~d},{ }^{4} J_{\mathrm{PC}} 1.9 \mathrm{~Hz}\right), 132.27\left(\mathrm{~d},{ }^{1} J_{\mathrm{PC}} 107.2 \mathrm{~Hz}\right), 135.07,135.07\left(\mathrm{~d},{ }^{2} J_{\mathrm{PC}} 7.3 \mathrm{~Hz}\right)$, $156.90\left(\mathrm{~d},{ }^{2} J_{\mathrm{PC}} 14.1 \mathrm{~Hz}\right), 165.10,165.46\left(\mathrm{~d},{ }^{3} J_{\mathrm{PC}} 10.9 \mathrm{~Hz}\right) .{ }^{31} \mathrm{P}-\mathrm{NMR}\left(121.4 \mathrm{MHz}, \mathrm{CDCl}_{3}\right) \delta$ (ppm) 20.10. MS (EI), m/z: $443\left(\mathrm{M}^{+}, 22 \%\right), 384$ (13\%), 320 (4\%), 230 (16\%), 200 (88\%). Analysis: Calcd (\%) for $\mathrm{C}_{26} \mathrm{H}_{22} \mathrm{NO}_{4} \mathrm{P}: \mathrm{C}, 70.43$; H, 4.97; N, 3.16. Found: C, 70.46; H, 4.95; N, 3.18 .

Mehtyl (2E)-[5-cyclohexyl-2-oxo-4-(diphenylphosphoryl)-1,2-dihydro-3H-pyrrol-3-ylidene] acetate (11c). Yield >97\%. M.p. $248{ }^{\circ} \mathrm{C}$. IR $v\left(\mathrm{~cm}^{-1}\right)$ 3490, 1730, 1437, 1165. ${ }^{1} \mathrm{H}-\mathrm{NMR}(300.13$ $\left.\mathrm{MHz}, \mathrm{CDCl}_{3}\right) \delta(\mathrm{ppm})$ 0.80-1.70 (m, 10H), $2.37(\mathrm{~m}, 1 \mathrm{H}), 3.72(\mathrm{~s}, 3 \mathrm{H}), 6.52(\mathrm{~s}, 1 \mathrm{H}), 7.50-8.00$ (m, 10H, HAr), 9.28 (s, 1H, NH). ${ }^{13} \mathrm{C}-\mathrm{NMR}\left(75.46 \mathrm{MHz}, \mathrm{CDCl}_{3}\right) \delta$ (ppm) 22.15, 25.54, 29.85, $37.03,52.04,98.12$ (d, $\left.{ }^{1} J_{\mathrm{PC}} 126.5 \mathrm{~Hz}\right), 126.04,128.80\left(\mathrm{~d},{ }^{3} J_{\mathrm{PC}} 12.6 \mathrm{~Hz}\right), 131.59\left(\mathrm{~d},{ }^{2} J_{\mathrm{PC}} 10.6\right.$ $\mathrm{Hz}), 132.27,133.11$ (d, $\left.{ }^{1} J_{\mathrm{PC}} 108.5 \mathrm{~Hz}\right), 135.65$ (d, $\left.{ }^{2} J_{\mathrm{PC}} 8.4 \mathrm{~Hz}\right), 164.66$ (d, $\left.{ }^{2} J_{\mathrm{PC}} 15.4 \mathrm{~Hz}\right), 166.65$, $168.53\left(\mathrm{~d},{ }^{3} J_{\mathrm{PC}} 11.1 \mathrm{~Hz}\right) .{ }^{31} \mathrm{P}-\mathrm{NMR}\left(121.4 \mathrm{MHz}, \mathrm{CDCl}_{3}\right) \delta(\mathrm{ppm}) 21.90 . \mathrm{MS}(\mathrm{EI}), \mathrm{m} / z: 435\left(\mathrm{M}^{+}\right.$, 13\%), 376 (14\%), 346 (4\%), 200 (70\%). Analysis: Calcd (\%) for $\mathrm{C}_{25} \mathrm{H}_{26} \mathrm{NO}_{4} \mathrm{P}: \mathrm{C}, 68.97 ; \mathrm{H}, 5.98$; N, 3.22. Found: C, 69.00; H, 5.96; N, 3.22.

Mehtyl (2E)-[5-tert-butyl-2-oxo-4-(diphenylphosphoryl))-1,2-dihydro-3H-pyrrol-3-ylidene] acetate (11d). Yield >97\%. M.p. $193{ }^{\circ} \mathrm{C}$. IR $v\left(\mathrm{~cm}^{-1}\right)$ 3445, 1731, 1624, 1438, 1212. ${ }^{1} \mathrm{H}-\mathrm{NMR}$ $\left(300.13 \mathrm{MHz}, \mathrm{CDCl}_{3}\right) \delta(\mathrm{ppm}) 1.47(\mathrm{~s}, 9 \mathrm{H}), 3.75(\mathrm{~s}, 3 \mathrm{H}), 5.15(\mathrm{~s}, 1 \mathrm{H}), 7.40-7.80$ (m, 10H, HAr), $8.20(\mathrm{~s}, 1 \mathrm{H}, \mathrm{NH}) .{ }^{13} \mathrm{C}-\mathrm{NMR}\left(75.46 \mathrm{MHz}, \mathrm{CDCl}_{3}\right) \delta(\mathrm{ppm}) 29.40,35.10,52.37,98.13\left(\mathrm{~d},{ }^{1} J_{\mathrm{PC}}\right.$ $125.0 \mathrm{~Hz}), 125.77,128.84\left(\mathrm{~d},{ }^{3} J_{\mathrm{PC}} 12.5 \mathrm{~Hz}\right), 131.63\left(\mathrm{~d},{ }^{2} J_{\mathrm{PC}} 10.4 \mathrm{~Hz}\right), 132.17,133.79\left(\mathrm{~d},{ }^{1} J_{\mathrm{PC}}\right.$ $109.4 \mathrm{~Hz}$ ), 136.65 (d, $\left.{ }^{2} J_{\mathrm{PC}} 9.2 \mathrm{~Hz}\right), 166.80$ (d, $\left.{ }^{2} J_{\mathrm{PC}} 21.7 \mathrm{~Hz}\right), 166.82,171.00\left(\mathrm{~d},{ }^{3} J_{\mathrm{PC}} 12.6 \mathrm{~Hz}\right)$. ${ }^{31} \mathrm{P}-\mathrm{NMR}\left(121.4 \mathrm{MHz}, \mathrm{CDCl}_{3}\right) \delta(\mathrm{ppm})$ 21.90. MS (EI), m/z: $409\left(\mathrm{M}^{+}, 12 \%\right), 349(48 \%), 200$ (100\%). Analysis: Calcd (\%) for $\mathrm{C}_{23} \mathrm{H}_{24} \mathrm{NO}_{4} \mathrm{P}: \mathrm{C}, 67.48 ; \mathrm{H}, 5.87$; N, 3.42. Found: C, 67.44; H, $5.86 ; \mathrm{N}, 3.40$.

General procedure for the synthesis of 2-pyridones 12 and 3-pyrrolidone 13. A solution of the acyclic derivative $\mathbf{1 0}(5 \mathrm{mmol})$ in dry toluene was heated for $12 \mathrm{~h}$ at reflux. Evaporation of the mixture under reduced pressure afforded a crude solid that contains a mixture of 2pyrrolidone 11 and 2-pyridone 12 (3-pyrrolidoen 13 when 10d was used as starting material). The separation of the mixture was carried out through fractionated recrystallization or, in the case of compound $\mathbf{1 2 b}$, column chromatography using ethyl acetate $\left(\mathrm{R}_{\mathrm{f}}=0.50\right)$ as eluent.

Methyl 6-(4-methylphenyl)-2-oxo-5-(diphenylphosphoryl)-1,2-dihydropyridine-4carboxylate (12a). Yield 65\%. M.p. $210^{\circ} \mathrm{C}$. IR $v\left(\mathrm{~cm}^{-1}\right) 3435,1726,1666,1437,1195 .{ }^{1} \mathrm{H}-\mathrm{NMR}$ $\left(300.13 \mathrm{MHz}, \mathrm{CDCl}_{3}\right) \delta(\mathrm{ppm}) 2.40(\mathrm{~s}, 3 \mathrm{H}), 3.35(\mathrm{~s}, 3 \mathrm{H}), 6.85\left(\mathrm{~d}, 1 \mathrm{H},{ }^{4} J_{\mathrm{PH}} 2.4 \mathrm{~Hz},\right), 6.89(\mathrm{~m}, 2 \mathrm{H}$, 
HAr), 7.10-7.40 (m, 6H, HAr), 7.45-7.60 (m, 4H, HAr). ${ }^{13} \mathrm{C}-\mathrm{NMR}\left(100.61 \mathrm{MHz}, \mathrm{CDCl}_{3}\right) \delta$ (ppm) 21.28, 52.45, $107.70\left(\mathrm{~d},{ }^{1} J_{\mathrm{PC}} 113.5 \mathrm{~Hz}\right), 120.19\left(\mathrm{~d},{ }^{3} J_{\mathrm{PC}} 8.2 \mathrm{~Hz}\right), 127.90\left(\mathrm{~d},{ }^{3} J_{\mathrm{PC}} 12.2 \mathrm{~Hz}\right)$, 128.96, 129.55, $130.56\left(\mathrm{~d},{ }^{3} J_{\mathrm{PC}} 3.2 \mathrm{~Hz}\right), 130.84\left(\mathrm{~d},{ }^{4} J_{\mathrm{PC}} 2.0 \mathrm{~Hz}\right), 130.99\left(\mathrm{~d},{ }^{2} J_{\mathrm{PC}} 9.4 \mathrm{~Hz}\right), 134.19$ $\left(\mathrm{d},{ }^{1} J_{\mathrm{PC}} 109.3 \mathrm{~Hz}\right), 140.92,148.48\left(\mathrm{~d},{ }^{2} J_{\mathrm{PC}} 7.9 \mathrm{~Hz}\right), 157.29\left(\mathrm{~d},{ }^{2} J_{\mathrm{PC}} 15.8 \mathrm{~Hz}\right), 162.76,166.45 .{ }^{31} \mathrm{P}-$ NMR (121.4 MHz, $\left.\mathrm{CDCl}_{3}\right) \delta(\mathrm{ppm})$ 22.80. MS (EI), m/z: $443\left(\mathrm{M}^{+}, 27 \%\right), 428(90 \%), 383$ (35\%), 333 (25\%), 200 (52\%). Analysis: Calcd (\%) for $\mathrm{C}_{26} \mathrm{H}_{22} \mathrm{NO}_{4} \mathrm{P}: \mathrm{C}, 70.43$; H, 4.97; N, 3.16. Found: C, 70.48; H, 4.96; N, 3.17.

Methyl 6-(2-methylphenyl)-2-oxo-5-(diphenylphosphoryl)-1,2-dihydropyridine-4carboxylate (12b). Yield 30\%. M.p. $155^{\circ} \mathrm{C}$. IR $v\left(\mathrm{~cm}^{-1}\right) 3426,1735,1680,1438,1118 .{ }^{1} \mathrm{H}-\mathrm{NMR}$ $\left(400.13 \mathrm{MHz}, \mathrm{CDCl}_{3}\right) \delta(\mathrm{ppm}) 1.74(\mathrm{~s}, 3 \mathrm{H}), 3.34(\mathrm{~s}, 3 \mathrm{H}), 6.66(\mathrm{~m}, 1 \mathrm{H}, \mathrm{HAr}), 6.67\left(\mathrm{~d}, 1 \mathrm{H},{ }^{4} J_{\mathrm{PH}}\right.$ $2.5 \mathrm{~Hz}$ ), 6.89 (m, 1H, HAr), 7.02 (m, 1H, HAr), 7.08 (m, 1H, HAr), 7.10 (m, 2H, HAr), 7.307.33 (m, 4H, HAr), 7.51-7.58 (m, 4H, HAr). ${ }^{13} \mathrm{C}-\mathrm{NMR}\left(100.61 \mathrm{MHz}, \mathrm{CDCl}_{3}\right) \delta$ (ppm) 18.98, $51.58,100.65\left(\mathrm{~d},{ }^{1} J_{\mathrm{PC}} 112.2 \mathrm{~Hz}\right), 119.22\left(\mathrm{~d},{ }^{3} J_{\mathrm{PC}} 7.9 \mathrm{~Hz}\right), 124.39,126.86\left(\mathrm{~d},{ }^{3} J_{\mathrm{PC}} 12.4 \mathrm{~Hz}\right)$, $126.90\left(\mathrm{~d},{ }^{3} J_{\mathrm{PC}} 12.7 \mathrm{~Hz}\right), 129.20,129.52,129.66,130.11\left(\mathrm{~d},{ }^{4} J_{\mathrm{PC}} 2.8 \mathrm{~Hz}\right), 130.21\left(\mathrm{~d},{ }^{4} J_{\mathrm{PC}} 2.9\right.$ $\mathrm{Hz}), 130.37\left(\mathrm{~d},{ }^{2} J_{\mathrm{PC}} 10.3 \mathrm{~Hz}\right), 130.39\left(\mathrm{~d},{ }^{2} J_{\mathrm{PC}} 9.8 \mathrm{~Hz}\right), 131.42\left(\mathrm{~d},{ }^{3} J_{\mathrm{PC}} 2.8 \mathrm{~Hz}\right), 131.44\left(\mathrm{~d},{ }^{1} J_{\mathrm{PC}}\right.$ 102.4 Hz), 131.67 (d, $\left.{ }^{1} J_{\mathrm{PC}} 100.3 \mathrm{~Hz}\right), 135.14,147.99\left(\mathrm{~d},{ }^{2} J_{\mathrm{PC}} 7.5 \mathrm{~Hz}\right), 153.95\left(\mathrm{~d},{ }^{2} J_{\mathrm{PC}} 16.3 \mathrm{~Hz}\right)$, 161.43, $165.97\left(\mathrm{~d},{ }^{3} J_{\mathrm{PC}} 2.1 \mathrm{~Hz}\right) .{ }^{31} \mathrm{P}-\mathrm{NMR}\left(121.4 \mathrm{MHz}, \mathrm{CDCl}_{3}\right) \delta(\mathrm{ppm}) 26.00$. MS (EI), $m / z$ : $442\left(\mathrm{M}^{+}-1,3 \%\right), 351$ (61\%), 242 (100\%). Analysis: Calcd (\%) for $\mathrm{C}_{26} \mathrm{H}_{22} \mathrm{NO}_{4} \mathrm{P}: \mathrm{C}, 70.43 ; \mathrm{H}$, 4.97; N, 3.16. Found: C, 70.48; H, 4.96; N, 3.17.

Methyl 6-cyclohexyl-2-oxo-5-(diphenylphosphoryl)-1,2-dihydropyridine-4-carboxylate (12c). Yield 40\%. M.p. $267{ }^{\circ} \mathrm{C}$. IR $v\left(\mathrm{~cm}^{-1}\right)$ 3400, 1724, 1657, 1437, 1119. ${ }^{1} \mathrm{H}-\mathrm{NMR}(400.13$ $\left.\mathrm{MHz}, \mathrm{CDCl}_{3}\right) \delta(\mathrm{ppm})$ 0.70-0.90 (m, 5H), 1.50-1.60 (m, 2H), 2.90 (s, 1H), 3.72 (s, 3H), 6.54 (d, $1 \mathrm{H},{ }^{4} J_{\mathrm{PH}} 2.4 \mathrm{~Hz}$ ), 7.50-7.80 (m, 10H, HAr), 11.90 (s, 1H, NH). ${ }^{13} \mathrm{C}-\mathrm{NMR}\left(100.61 \mathrm{MHz}, \mathrm{CDCl}_{3}\right)$ $\delta(\mathrm{ppm}) 24.91,25.43,31.57,42.30\left(\mathrm{~d},{ }^{3} J_{\mathrm{PC}} 3.5 \mathrm{~Hz}\right), 52.60,105.12\left(\mathrm{~d},{ }^{1} J_{\mathrm{PC}} 113.7 \mathrm{~Hz}\right), 117.96(\mathrm{~d}$, $\left.{ }^{3} J_{\mathrm{PC}} 8.5 \mathrm{~Hz}\right), 128.82\left(\mathrm{~d},{ }^{3} J_{\mathrm{PC}} 12.6 \mathrm{~Hz}\right), 131.59\left(\mathrm{~d},{ }^{2} J_{\mathrm{PC}} 10.5 \mathrm{~Hz}\right), 132.10\left(\mathrm{~d},{ }^{4} J_{\mathrm{PC}} 1.8 \mathrm{~Hz}\right), 133.39$ $\left(\mathrm{d},{ }^{1} J_{\mathrm{PC}} 108.5 \mathrm{~Hz}\right), 149.43\left(\mathrm{~d},{ }^{2} J_{\mathrm{PC}} 8.0 \mathrm{~Hz}\right), 162.01\left(\mathrm{~d},{ }^{2} J_{\mathrm{PC}} 15.9 \mathrm{~Hz}\right), 163.83,167.41\left(\mathrm{~d},{ }^{3} J_{\mathrm{PC}} 2.4\right.$ Hz). ${ }^{31} \mathrm{P}-\mathrm{NMR}\left(121.4 \mathrm{MHz}, \mathrm{CDCl}_{3}\right) \delta$ (ppm) 29.10. MS (EI), $m / z: 435\left(\mathrm{M}^{+},<3 \%\right), 420(31 \%)$, 341 (14\%), 200 (49\%). Analysis: Calcd (\%) for $\mathrm{C}_{25} \mathrm{H}_{26} \mathrm{NO}_{4} \mathrm{P}: \mathrm{C}, 68.97$; H, 5.98; N, 3.22. Found: C, 768.95; H, 5.99; N, 3.20.

Methyl [5-tert-butyl-5-hydroxy-4-oxo-2-(diphenylphosphoryl)-4,5-dihydro-1 H-pyrrol-3yl]acetate (13). Yield 33\%. M.p. $201{ }^{\circ} \mathrm{C}$. IR $v\left(\mathrm{~cm}^{-1}\right) 3223,1751,1733,1705,1439,1161 .{ }^{1} \mathrm{H}-$ NMR (300.13 MHz, $\left.\mathrm{CDCl}_{3}\right) \delta(\mathrm{ppm}) 0.96(\mathrm{~s}, 9 \mathrm{H}), 2.60\left(\mathrm{~d}, 1 \mathrm{H},{ }^{2} J_{\mathrm{HH}} 16.8 \mathrm{~Hz}\right), 2.92\left(\mathrm{dd}, 1 \mathrm{H},{ }^{2} J_{\mathrm{HH}}\right.$ $\left.16.8 \mathrm{~Hz},{ }^{4} J_{\mathrm{PH}} 1.9 \mathrm{~Hz}\right), 3.61(\mathrm{~s}, 3 \mathrm{H}), 6.39(\mathrm{~s}, 1 \mathrm{H}, \mathrm{OH}), 7.40-7.80(\mathrm{~m}, 7 \mathrm{H}, \mathrm{HAr}, \mathrm{NH}), 7.85-7.95(\mathrm{~m}$, $4 \mathrm{H}, \mathrm{HAr}) .{ }^{1} \mathrm{H}-\mathrm{NMR}\left(300.13 \mathrm{MHz}, \mathrm{DMSO}-d_{6}\right) \delta(\mathrm{ppm}) 0.89(\mathrm{~s}, 9 \mathrm{H}), 2.88(\mathrm{~s}, 2 \mathrm{H}), 3.47(\mathrm{~s}, 3 \mathrm{H})$, 6.37 (s, 1H, OH), 7.40-7.80 (m, 10H, HAr), 9.10 (s, 1H, NH). ${ }^{13} \mathrm{C}-\mathrm{NMR}\left(75.46 \mathrm{MHz}, \mathrm{DMSO}-d_{6}\right)$ $\delta(\mathrm{ppm}) 26.30,31.28,39.80,51.81,97.07$ (d, $\left.{ }^{3} J_{\mathrm{PC}} 9.8 \mathrm{~Hz}\right), 128.39$ (d, $\left.{ }^{3} J_{\mathrm{PC}} 12.4 \mathrm{~Hz}\right), 129.44(\mathrm{~d}$, $\left.{ }^{3} J_{\mathrm{PC}} 12.2 \mathrm{~Hz}\right), 130.79\left(\mathrm{~d},{ }^{2} J_{\mathrm{PC}} 9.7 \mathrm{~Hz}\right), 131.73\left(\mathrm{~d},{ }^{2} J_{\mathrm{PC}} 10.4 \mathrm{~Hz}\right), 132.01,132.46,132.88\left(\mathrm{~d},{ }^{1} J_{\mathrm{PC}}\right.$ $106.5 \mathrm{~Hz}), 134.29\left(\mathrm{~d},{ }^{1} J_{\mathrm{PC}} 107.2 \mathrm{~Hz}\right), 145.04$ (d, $\left.{ }^{2} J_{\mathrm{PC}} 5.8 \mathrm{~Hz}\right), 148.33\left(\mathrm{~d},{ }^{1} J_{\mathrm{PC}} 103.08 \mathrm{~Hz}\right)$, 168.13, 168.39. ${ }^{31} \mathrm{P}-\mathrm{NMR}\left(121.4 \mathrm{MHz}, \mathrm{CDCl}_{3}\right) \delta(\mathrm{ppm})$ 29.10. ${ }^{31} \mathrm{P}-\mathrm{NMR}$ (121.4 MHz, DMSO- 
$\left.d_{6}\right) \delta(\mathrm{ppm})$ 21.30. MS (EI), m/z: $369\left(\mathrm{M}^{+}-59,28 \%\right), 337$ (50\%), 200 (100\%). Analysis: Calcd (\%) for $\mathrm{C}_{23} \mathrm{H}_{26} \mathrm{NO}_{4} \mathrm{P}: \mathrm{C}, 64.64 ; \mathrm{H}, 6.09 ; \mathrm{N}, 3.28$. Found: C, 64.60; H, 6.10; N, 3.25.

\section{Acknowledgements}

Financial support through Ministerio de Educación, Cultura y Deporte (Project CTQ2005-01792) is gratefully acknowledged.

\section{References and Footnotes}

1. Patent, SmithKline Beecham 1991, GB 91/24577, Chem. Abstr. 1993, 119, 180664. (b) Haase, M.; Günther, W.; Görls, H.; Anders, E. Synthesis 1999, 2071. (c) Patent, Jomaa, H. WO 1999 EP10274, Chem. Abstr. 2000, 133, 68911. (d) Moonen, K.; Laureyn, I.; Stevens, C. V. Chem. Rev. 2004, 104, 6177.

2. Granik, V. G.; Makarov, V. A.; Párkányi, C. Adv. Heterocycl. Chem. 1999, 72, 283.

3. Barluenga, J.; Merino, I.; Palacios, F. J. Chem. Soc., Perkin Trans. 1 1991, 341.

4. (a) Palacios, F.; Aparicio, D.; de los Santos, J. M. Tetrahedron 1996, 52, 4123. (b) Palacios, F.; Aparicio, D.; Ochoa de Retana, A. M.; Oyarzabal, J. Tetrahedron 1999, 55, 3105. (c) Palacios, F.; Ochoa de Retana, A. M.; Gil, J. I.; Ezpeleta, J. M. J. Org. Chem. 2000, 65, 3213. (d) Palacios, F.; Aparicio, D.; de los Santos, J. M.; Vicario, J. Tetrahedron 2001, 57, 1961. (e) Palacios, F.; Aparicio, D.; García, J.; Vicario, J.; Ezpeleta, J. M. Eur. J. Org. Chem. 2001, 3357, and references therein. (f) Palacios, F.; Aparicio, D.; Vicario, J. Eur. J. Org. Chem. 2002, 4131. (g) Kozlov, V. A.; Odinets, I. L.; Lyssenko, K. A.; Churusova, S. G.; Yarovenko, S. V.; Petrovskii, P. V.; Mastryukova, T. A. Heteroatom Chem. 2005, 16, 159.

5. Alikin, A.Y.; Sokolov, M.P.; Liorber, B.G.; Razumov, A.I.; Zykova, T.V.; Zykova, V.V.; Suleimanova, I.N. J. Gen. Chem. USSR 1981, 51, 435. (b) Palacios, F.; García, A.; Ochoa de Retana, A. M.; Oyarzabal, J. Heterocycles 1995, 41, 1915. (c) Palacios, F.; Aparicio, D.; García, J. Tetrahedron 1997, 53, 2931. (d) Palacios, F.; García, A.; Ochoa de Retana, A. M.; Oyarzabal, J. Tetrahedron 1999, 55, 5947. (e) Abdou, W. M.; El-khoshnie, Y. O.; Salem, M. A. I.; Borghash, R. F. Synlett 2002, 1417. (f) Palacios, F.; Ochoa de Retana, A. M.; Martínez de Marigorta, E.; Rodríguez, M.; Pagalday, J. Tetrahedron 2003, 59, 2617.

6. López-Ortiz, F.; Peláez-Arango, E.; Palacios, F.; Barluenga, J.; García-Granda, S.; Tejerina, B; García-Fernández A. J. Org. Chem. 1994, 59, 1984. (b) Peláez-Arango, E; López-Ortiz, F. J. Chem. Soc., Perkin Trans. 1 1996, 1481. (c) López-Ortiz, F. Curr. Org. Synthesis 2006, 3, 187.

7. Palacios, F.; Ochoa de Retana, A.M.; Pascula, S.; López de Munain, R.; Oyarzabal, J.;

Ezpeleta, J.M. Tetrahedron 2005, 61, 1087, and references therein. 
8. Barluenga J., López-Ortiz, F.; Palacios, F. Tetrahedron Lett. 1987, $28,2875$.

9. (a) Barluenga, Ferrero, M.; López-Ortiz, F.; Palacios, F. J. Chem. Soc., Perkin Trans. 1. 1989, 615. (b) Jang, W. B.; Lee, K.; Le, C. W.; Oh, D. Y. Chem. Commun. 1998, 609.

10. For a review see: Hiratake, J.; Oda, J. Biosci. Biotech. Biochem. 1997, 61, 211. (b) Valiaeva, N.; Bartley, D.; Konno, T.; Coward, J. K. J. Org. Chem. 2001, 66, 5146.

11. Akazome, M.; Suzuki, S.; Shimizu, Y.; Henmi, K.; Ogura, K. J. Org. Chem. 2000, 65, 6917.

12. Barluenga, López-Ortiz, F.; Palacios, F. J. Chem. Research. Synop. 1985, 211; J. Chem. Research. Miniprint 2541.

13. (a) Seyferth, D.; Welch, D. E.; Heeren, J. K. J. Am. Chem. Soc. 1963, 85, 642. (b) Seyferth, D.; Welch, D. E.; Heeren, J. K. J. Am. Chem. Soc. 1964, 86, 1100.

14. Wiseman, J. R.; Krabbenhoff, H. O. J. Org. Chem. 1976, 41, 589. (b) Quin, L. D.; Gallagher, M. J.; Cunkle, G. T.; Chesnut, D. R. J. Am. Chem. Soc. 1980, 102, 3136. (c) Duncan, M.; Gallagher, M. J. Org. Magn. Reson. 1981, 15, 37.

15. The $Z$ configuration of the enamine moiety was assigned based on the magnitude of the coupling of the quaternary carbon of the $t$-Bu substituent with the phosphorus, ${ }^{3} J_{\mathrm{PC}}=10 \mathrm{~Hz}$, and the NOE observed between these methyl protons and one methoxy group. The NOE enhancement of the ortho protons of the phenyl rings linked to the phosphorus produced by saturating the olefinic proton of the dienic system established the $E$ configuration of this double bond.

16. (a)Beagley, B.; Bitrus, P.; Booth, B. L. Pritchard, R. G. J. Chem. Soc., Perkin Trans. 1 1993, 1039. (b) Clegg, W.; Davies, R. P.; Dunbar, L.; Feeder, N.; Liddle, S. T.; Mulvey, R. E.; Snaith, R.; Wheatley, A. E. H. Chem. Commun. 1999, 1401.

17. Bax, A.; Davis, D. G. J. Magn. Reson. 1985, 63, 207. (b) Bothner-By, A. A.; Stephens, R. L.; Lee, J.; Warren, C. D.; Jeanloz, R. W. J. Am. Chem. Soc. 1984, 106, 811. The E configuration of the carbon-carbon double bond was deduced from the NOE observed between the olefinic proton and the aromatic protons of the diphenylphosphoryl moiety.

18. The ${ }^{13} \mathrm{C}$ NMR spectrum measured at $-60{ }^{\circ} \mathrm{C}$ showed signals for the two isomers. The broad signal observed in the room temperature spectrum for the methine carbon bonded to phosphorus split in two doublets at $\delta 44.94,{ }^{1} J_{\mathrm{PC}}=60.7 \mathrm{~Hz}$, and $\delta 46.48,{ }^{1} J_{\mathrm{PC}}=61.2 \mathrm{~Hz}$. The two quaternary carbons of the $t$-Bu group appeared at $\delta 41.35,{ }^{3} J_{\mathrm{PC}}=3.3 \mathrm{~Hz}$, and $\delta 41.91$, ${ }^{3} J_{\mathrm{PC}}=2.8 \mathrm{~Hz}$.

19. Similar reactivity has been observed for $N$-acylacetamidrazones and diethyl acetylendicarboxylate. Bernard, A. M.; Cocco, M. T.; Congiu, C.; Onnis, V.; Piras, P. P. Heterocycles 1995, 41, 1479.

20. (a) Patent, Amgen Inc. Int., Appl. WO 20011044230, Chem. Abstr. 2001, 135, 61230. (b) Qiao, L.; Zhao, L. Y.; Rong, S. B.; Wu, X. W.; Wang, S.; Fujii, T.; Kazanietz, M. G.; Rauser, L.; Savage, J.; Roth, B. L.; Flippen-Anderson, J.; Kozikowski, A. P. Bioorg. Med. Chem. Lett. 2001, 11, 955.

21. The heterocyclic framework was identified through the four correlations observed for the $\mathrm{NH}$ proton $(\delta 9.1)$ with the carbons at $\delta 97.07\left(\mathrm{~d},{ }^{3} J_{\mathrm{PC}}=9.8 \mathrm{~Hz}\right), 145.04\left(\mathrm{~d},{ }^{2} J_{\mathrm{PC}}=5.8 \mathrm{~Hz}\right)$, 
$148.33\left(\mathrm{~d},{ }^{1} J_{\mathrm{PC}}=103.8 \mathrm{~Hz}\right)$, and 168.13 . The $\mathrm{OH}$ proton at $\delta 6.37$ correlated with the carbon at $\delta 97.07$ and the quaternary carbon of the $t$-Bu group, implying that both substituents are linked to that heterocyclic carbon.

22. Oki, M. In Applications of Dynamic NMR Spectroscopy to Organic Synthesis; VCH: Weinheim, 1985.

23. (a) Andrews, D. M.; Gregoriou, M.; Page, T. C. M.; Peach, J. M.; Pratt, A. J. J. Chem. Soc., Perkin Trans. 1 1995, 1335. (b) Balasubramanian, M.; Keay, J. G. In Comprehensive Heterocyclic Chemistry II; Katritzky, A. R.; Rees, C. W.; Scriven, E. F. V., Eds. Pergamon Press: Amsterdam, 1996, Vol. 5, pp 245. (c) Zhang, S.; Liebeskind, L. J. Org. Chem. 1999, $64,4042$. 